Canadian

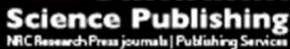

Canadian Journal of Microbiology Revue canadienne de de microbiologie

\title{
The oral cavity microbiota: between health, oral disease and cancers of the aerodigestive tract
}

\begin{tabular}{|r|l|}
\hline Journal: & Canadian Journal of Microbiology \\
\hline Manuscript ID & cjm-2016-0603.R1 \\
\hline Manuscript Type: & Review \\
\hline Date Submitted by the Author: & 26 -Dec-2016 \\
\hline Complete List of Authors: & $\begin{array}{l}\text { Le Bars, Pierre; Universite de Nantes, Prosthtodontic } \\
\text { Metamoros, Sebastien; Universite Catholique de Louvain La Faculte de } \\
\text { Medecine, Walloon Excellence in Life Sciences and BIotechnology, Louvain } \\
\text { Drug Research Institute, Metabolism and Nutrition Research Group, } \\
\text { Louvain Drug Research Institute } \\
\text { Montassier, Emmanuel; Centre Hospitalier Universitaire de Nantes, } \\
\text { Université de Nantes, CHU - Hôtel-Dieu, EA 3826 Thérapeutiques cliniques } \\
\text { et expérimentales des infections, } \\
\text { Le Vacon, Françoise; Biofortis Innovation Services - Mérieux NutriSciences, } \\
\text { Potel, Gilles; Université de Nantes, CHU - Hôtel-Dieu, EA 3826 } \\
\text { Thérapeutiques cliniques et expérimentales des infections, Faculté de } \\
\text { médecine, Faculté de médecine } \\
\text { Soueidan, Assem; Universite de Nantes, periodontology } \\
\text { Jordana, Fabienne; Universite de Nantes, Université de Nantes. CHU - } \\
\text { Hôtel-Dieu. UFR d'odontologie, UIC Odontologie } \\
\text { De La Cochétière, Marie-France; Universite de Nantes, Université de } \\
\text { Nantes, EA 3826 Thérapeutiques cliniques et expérimentales des } \\
\text { infections, Faculté de médecine }\end{array}$ \\
\hline \multirow{2}{*}{ Keyword: } & \begin{tabular}{l} 
Upper aerodigestive, microbiome, oral cavity, carcinogenesis \\
\hline
\end{tabular} \\
\hline
\end{tabular}

\section{SCHOLARONE \\ Manuscripts}


The oral cavity microbiota: between health, oral disease and cancers of the aerodigestive tract

Pierre Le Bars ${ }^{1}$, Sébastien Matamoros ${ }^{2}$, Emmanuel Montassier ${ }^{3}$, Françoise Le Vacon ${ }^{4}$, Gilles Potel ${ }^{3}$, Assem Soueidan ${ }^{1}$, Fabienne Jordana ${ }^{1 *}$, Marie-France de La Cochetière $5^{*}\left({ }^{*}\right.$ : co-last-authors)

1- Université de Nantes. CHU - hôtel-Dieu. UFR d'odontologie, UIC Odontologie, 1 place Alexis Ricordeau, BP 84215, 44042 Nantes Cedex 1, France, Email address: Pierre.Le-Bars@univ-nantes.fr 2- Walloon Excellence in Life Sciences and Biotechnology, Louvain Drug Research Institute, Metabolism and Nutrition Research Group, Louvain Drug Research Institute ; Université catholique de Louvain, Place de I'Université 1, 1348 Brussels, Belgium, Email address: sebastien.matamoros@gmail.com 3- Université de Nantes, CHU - Hôtel-Dieu, EA 3826 Thérapeutiques cliniques et expérimentales des infections, Faculté de médecine, 1 Rue G. Veil, 44000 Nantes, France. Email address::

Emmanuel.Montassier@univ-nantes.fr

4- Biofortis Innovation Services - Mérieux NutriSciences, 3 Route de la Chatterie, 44800 SaintHerblain. Email address:: francoise.le.vacon@mxns.com

5- Université de Nantes, EA 3826 Thérapeutiques cliniques et expérimentales des infections, Faculté de médecine, 1 Rue G. Veil, 44000 Nantes, France. Email address: marie-france.de-lacochetiere@univ-nantes.fr

Corresponding author: Assem Soueidan

Address: Faculty of Dentistry, 1 Place Alexis Ricordeau, BP 84215, 44042 Nantes cedex 1, France.

Email address: assem.soueidan@univ-nantes.fr. Phone number: +33 240412923. Fax number: +33 2

40201867 


\section{Abstract}

Many studies show that the human microbiome plays a critical role in the chronic pathologies of obesity, inflammatory bowel diseases, and diabetes.

More recently, the interaction between cancer and the microbiome has been highlighted. Most studies have focused on the gut microbiota because it represents the most extensive bacterial community, and the body of evidence correlating it with gut syndromes is increasing. However, in the strict sense, the gastrointestinal (GI) tract begins in the oral cavity, and special attention should be paid to the specific flora of this cavity. This study reviewed the current knowledge about the various microbial ecosystems of the upper part of the GI tract and discussed their potential link to carcinogenesis. The overall composition of the microbial communities, as well as the presence or absence of 'key species' in relation to carcinogenesis, is addressed. Alterations in the oral microbiota can potentially be used to predict the risk of cancer.

Molecular advances and the further monitoring of the microbiota will increase our understanding of the role of the microbiota in carcinogenesis and open new perspectives for future therapeutic and prophylactic modalities.

Keywords: Upper aerodigestive, microbiome, oral cavity, carcinogenesis 


\section{Introduction}

Every year, there are 12.7 million new cancer cases worldwide, and an estimated $16.1 \%$ are linked to infections. Approximately $15-20 \%$ of human tumors are initiated by inflammation-driven processes (Francescone et al. 2014).

The gastrointestinal (GI) tract can be considered not only a pipeline system from the oral cavity to the anus but also an entry point for nutrients and a point of contact between the immune system and the environment. Various microenvironments are scattered along this tract, each having a specific ecosystem with its own microbiome. The term 'gut microbiota' refers to the trillions of microorganisms residing in the intestine. A microbiota can be classified as a planktonic microbiota or a biofilm microbiota. The GI tract is integrated into multiple physiological processes of the host (Haiser and Turnbaugh 2012). The microbial communities of the oral cavity are among the most diverse in the body. The passageways between the oral and nasal cavities and between the oropharynx and nasopharynx are apparent (Bassis et al. 2015). It is possible for bacteria to enter the bloodstream, for example, from periodontitis, untreated carious lesions or wound healing. Members of the human microbiota community play an active role in carcinogenesis through DNA damage (as is the case with Escherichia coli) (Su et al. 2015) and chronic infection (as is the case with Helicobacter pylori) (Kipanyula et al. 2013).

To understand the correlation between the human microbiota and health or disease, many sites (such as the skin, mouth, and gut) must be considered. The classical Pasteurian concept of a single microbe causing an infection in a previously sterile tissue is challenged by the demonstration of interrelationships between the host and the microbiota, which can lead to pathogenesis under particular circumstances (Rogers et al. 2013). The diversity of microorganisms involved in these interactions requires a new way of looking at the microbial ecosystem as a whole (Lozupone et al. 2012). Microarray studies (Yu et al. 2014) are proposed to investigate the interactions between the oral microbiome, host proteins, and host cells. Many parameters, such as metabolic interactions and 
the essential genes of pathogens or commensal communities are well-known and a key to understanding the balance between health and disease (Wade 2013).

Search strategy: a literature search for articles published in PubMed/MEDLINE between 2000 and 2016 was performed using the following keywords: "Upper aero digestive", "microbiome", "oral cavity" and "carcinogenesis". Combinations of the keywords were also used. Article titles and abstracts were examined to exclude irrelevant articles and articles that had already been identified. Finally, additional articles were obtained from a review of the references in selected articles. One hundred and forty-four articles formed the basis of narrative review.

After a brief review of general and major oral diseases, this review aimed to evaluate the impact of the upper aerodigestive tract-specific microbiome on carcinogenesis (Table 1).

\section{The human upper aerodigestive tract microbiota: a complex system}

The human microbiota is considered to be a complex system of microorganisms with a metabolic potential rivaling that of the liver (Table 2). The human upper aerodigestive tract (HUAT) is a transition zone that is constantly exposed to both inhaled and ingested microbes from the upper and lower respiratory tracts, as well as those contained in the saliva. The HUAT can be divided into four areas, which will be described below.

1-The microbiota of the nasal cavity, sinuses, nostrils and nose

The nares are often colonized, predominantly with Staphylocoque. epidermidis, Staphylocoque aureus (20\% of the general population) and Corynebacteriaceae. S. aureus is an opportunistic pathogen that maintains a unique, complex relationship with the host immune system (Mulcahy and McLoughlin. 2016). The paranasal sinuses are sterile under physiologic conditions (Cho and Blaser 2012). The nasal cavity bacterial communities are dominated by Actinobacteria, Formicates and Proteobacteria (Bassis et al. 2014).

2- The microbiota of the nasopharynx

Many bacterial species colonize the nasopharynx (the upper respiratory tract) in a niche-specific manner at discrete anatomical sites (Bogaert et al. 2011). Staphylococcus aureus persistently 
colonizes the anterior nares of approximately one-fifth of the population and maintains a unique, complex relationship with the host immune system. Streptococcus pneumoniae is another opportunistic pathogen that inhabits the nasopharyngeal environment (Mulcahy et al. 2016).

3- The microbiota of the oropharynx behind the mouth

The microbiota of the human oral cavity is distinct from that of the colon and stool habitats. The culturable bacterial microbiota of the saliva is dominated by the Streptococcus, Prevotella and Veillonella genera, which comprise $70 \%$ of this microbiota (Nasidze et al. 2009).

The total surface area of the mouth cavity is about $214.7 \pm 12.9 \mathrm{~cm}^{2}$, and there is no significant difference due to gender in this regard. The teeth, keratinized epithelium and non-keratinized epithelium occupy about $20 \%, 50 \%$ and $30 \%$ of the total surface area, respectively (Collins and Dawes 1987). The mouth cavity includes the inner cheeks, hard and soft palates and tongue, with its connections to the pharynx. Each of these surfaces, along with the saliva and gingival crevices, contain their own microenvironments and harbor site-specific microbiota (Wilson and Nussey 2010). Another similarity exists between the oropharynx and saliva in relation to Firmicutes, Proteobacteria and Bacteroides: each site is numerically dominated by distinct families within this phylum.

4-The microbiota of the laryngopharynx

The pharynx is normally colonized by members of the Streptococcaceae family but it is sometimes colonized by the pathogens Streptococcus pneumoniae, S. pyogenes and Neisseria meningitidis. The distinction between these four areas is purely anatomic. With regard to the human microbiota, communication and balance exist between various human body niches. Each anatomical site is colonized by a niche-specific microbiota, with a distinct phylum-level distribution. Interpersonal variation exists in the composition of the microbiome community (Flores et al. 2014).

\section{Oral microbiota investigations using next-generation sequencing}

We have several ways of studying the oral microbiota. Culture-independent techniques, such as pyrosequencing (Roche 454) and sequencing by synthesis (Illumina), have recently emerged as the methods of choice for the analysis of these complex ecosystems. They are of great value for the 
investigation of the oral microbiota, which include many microorganism species, some of which are very difficult to culture (Wade 2013). 16 S rRNA sequencing has shown differences in oral microbiota diversity and composition between patients suffering from oral cavity squamous cell carcinoma and healthy controls (Guerrero-Preston et al. 2016). Similarly, the presence of the pathogens Porphyromonas gingivalis and Aggregatibacter actinomycetemconcomitans in the oral microbiota was associated with an elevated risk of pancreatic cancer (Fan et al. 2016). It is noteworthy that $16 \mathrm{~S}$ rRNA sequencing only determines the presence or abundance of bacterial species and thus only allows researchers to draw observational conclusions. Shotgun metagenomic sequencing will also reveal the associated metabolic pathways (Zheng et al. 2015), which may shed light on the causal relationship between the HUAT microbiota and carcinogenesis. However, to our knowledge, this is not yet the case.

\section{Factors influencing the stability of the HUAT microbiota}

Aging: The human microbiota has evolved over hundreds of thousands of years of microbe-human symbiosis. Several years ago, it was shown that the mouth microbiota evolves with age. Colonization begins at birth (Prince et al. 2014) when dynamic microbial colonization of the oral cavity begins (Nelson-Filho et al. 2013). The profile of the predominant phylum evolves during childhood and youth and has almost stabilized by adulthood (Human Microbiome Project Consortium 2012). Nevertheless, in young children, the nasopharyngeal microbiota varies seasonally.

The teeth are colonized by S. mutans and S. sanguinis when they first appear. Some strains of Streptococcaceae adhere well to the gingival mucosa and cheeks but not to hard tissues. The structure of the gingival mucosa promotes anaerobic species. The complexity of the oral microbiota increases with age. Around puberty, colonization with Bacteroidetes and Spirochetes begins (Aas et al. 2005). Additionally, age and pathological conditions may quantitatively modify the microbiota. For example, the age-related increase in the abundance of Streptococcus anginosus in the saliva may be carefully controlled because of its known relationship with diseases such as cancer (Morita et al. 2004). 
Location: The human microbiota differs significantly based on anatomical location (Mark Welch et al. 2014). The human GI tract harbors a vast number of microbes but has limited diversity at the phylum level as compared to the oral cavity (Park et al. 2015). At least 15 phyla have been detected, and the most predominant among these include Fusobacteria, Actinobacteria, Proteobacteria, Bacteroidetes and Spirochaetae (Rogers et al. 2013; Nadell et al, 2009). Most sites are dominated by the Streptococcus genus, which is followed in abundance by Haemophilus spp. in the buccal mucosa, Actinomyces spp. in the supragingival plaque and Prevotella spp. in the subgingival plaque (Cho and Blaser 2012). In contrast, the GI tract microbiota is composed primarily of the Bacteroidetes and Firmcutes phyla, as well as minor constituents such as Actinobacteria, Proteobacteria, and Verrucomicrobia (Lozupone et al. 2012).

Environment: The oral microbial composition is capable of affecting the balance of the oral cavity; the interactions between the resident flora depend on local environmental changes and the host's diet. The presence of nutritious flakes of epithelium and secretions makes the oral cavity a highly favorable environment for various bacteria.

The resident flora including planktonic bacteria, a product of many microorganisms, apoptotic eukaryotic cells and buccal wounds, which aid the host by occupying every possible colonization site and thus preventing the establishment of non-indigenous microorganisms. Temperature ( 33 to $37^{\circ} \mathrm{C}$ ), smoking, alcohol use, $\mathrm{pH}$ (which is neutral on the tongue and mucosal surfaces and alkaline in gingival crevices), redox potential (which is positive in the major oral sites and negative in gingival crevices), atmospheric pressure and light affect microbiota composition. It appears that the oral microbiota significantly contributes to the host's immunity because it maintains low levels of antibodies in the saliva and participates in the synthesis of vitamins.

\section{The HUAT microbiota and oral diseases}

The oral microbiota is associated with numerous oral diseases. However, in most cases, only correlations or associations, not causality, have been demonstrated. The major infectious pathologies of the buccal tissue (decays, gingivitis and periodontitis) are all polymicrobial in nature. 
Dental procedures can result in the inoculation of microbial germs from the microbiota of the mouth into the bloodstream. Young and Young (2005) isolated Group B Streptococcus and Peptostreptococcus from tumor and peritumoral white matter tissues.

The association between periodontitis and the oral microbiota has been extensively studied for several decades. Although the original culture-based descriptions of the oral microbiota were highly valuable in implicating bacterial species as etiological agents of periodontitis, culture-independent methods, such as polymerase chain reaction (PCR) amplification, have facilitated a much deeper and insightful understanding of these populations' dynamics. More recently, the phylogeny and diversity of the oral microbiota were characterized at an unprecedented level using high-throughput sequencing (Keijser et al. 2008).

To understand the role of infectious bacterial assemblages in periodontitis pathogenesis, it is essential to consider the interrelationships between the selected niche, the microbiota composition, and the host. These relationships modify the pathologies of oral diseases, and gaining insight into them requires time.

The archaea are different from other microorganisms. Present in dental calculus, this dietary residue consists of harmless organisms and pathogens associated with local and systemic infections (Huynh et al. 2016). Recently, studies have revealed the structure, role and genetic composition of the Archaea; it is known that they may be involved in the onset of disease, although not directly. The methanogens (Methanobrevibacter smithii, Methanobrevibacter oralis and Methanosphaera stadtmanae), the only archaea identified in humans, appear to aid in the development of bacteria that play direct roles in pathogenesis. Members of this domain can colonize the intestine, oral cavity and skin (Kanady et al. 2012). Archaea may affect oral health through interspecies hydrogen transfer and by favoring the growth of fermenting bacteria. For example, methanogens are often found in infected periodontal pockets and dental canals. M. oralis has been found in periodontal pockets. Furthermore, methanogens and sulfate-reducing bacteria have been found in association with colorectal cancer (Horz and Conrads 2011). Finally, methanogens are able to transform heavy metals and metalloids (such as bismuth and amalgamated mercury) into methylated derivatives, which are 
more toxic (Zahnd et al. 2012). This transformation of heavy metals and metalloids has not yet been investigated in the oral cavity.

\section{Periodontal diseases and poor plaque control in the biofilm are related to many general}

\section{diseases}

Periodontal disease, a form of chronic inflammation, affects more than $80 \%$ of human adults (Kim et al. 2013). It is a polymicrobial attack that destroys the periodontal ligament and supporting marrow that surrounds the teeth. The three main microbial pathogenic agents involved are known as the red complex (P. gingivalis, $T$. forsythensis, $T$ denticola). Other pathogens involved in periodontal diseases include Fusobacterium nucleatum, Prevotella intermedia and Treponema socranskii (Nasidze et al. 2009). P. gingivalis is an anaerobic, Gram-negative bacilli (Love et al. 1992). It can invade eukaryotic cells via the action of several virulence mechanisms, such as adhesion to epithelial cells, the inhibition of the host's immune system (for example, by decreased phagocytosis and the inhibition of leukocytes and immunoglobulin proteases), the inhibition of anti-oxidative systems and enhanced inflammation (Steffen et al. 2000). T. forsythensis, previously known as Bacteroides forsythus, is a Gram-negative, strictly anaerobic bacterium that is frequently found in periodontal pockets (Sakamoto et al. 2002).

\section{The HUAT microbiota and general disorders}

Many correlations exist between oral infections and diseases. Among these, we can list generalized diseases, such as rheumatoid arthritis (Zhang et al. 2015), cardiovascular disease (Ordovas and Mooser 2006) and pulmonary diseases (Scannapieco and Genco 1999), as well as brain and liver abscesses (Wagner et al. 2006). Other such illnesses include gastrointestinal cancer (Meurman and Gronroos 2010), breast cancer (Laidi et al. 2016), cirrhosis (Bajaj et al. 2015) and diabetes (Maruyama et al. 2007; Deshpande et al. 2010; Farag et al. 2011). More recently, links with pregnancy (Digiulio et al. 2015), the human immunodeficiency virus (HIV) (Kistler et al. 2015) and acquired immune deficiency syndrome (AIDS) have also been described (Zhang et al. 2015). 
Among human pathogens of the Spirochetes order, Gram-negative bacteria are pathogenic factors for several human diseases, such as syphilis (Treponema pallidum), Lyme disease (Borrelia burgdorferi) and pinta (Treponema carateum). T. denticola is strictly anaerobic, rapidly motile and has a great ability to adhere to host cells and tissues via certain proteins expressed on outer cell membranes and adhesions (Holt et al. 2005).

Recently, it was shown that polymicrobial oral disease, if systematically distributed, favors various pathologies, such as bacteremia, pulmonary bacterial diseases, and preterm birth. For example, during dental hygiene procedures, wounds may be inoculated with oral streptococci, which can travel via the bloodstream and cause bacterial endocarditis. Patients with cardiovascular disease, numerous subgingival infections of Porphyromonas gingivalis and Tannerella forsythia and modestly higher levels of anti-hHSP60 (anti-human heat shock protein 60) antibodies have been described (Leishman et al. 2012).

\section{The HUAT microbiota and cancers}

Patients with oral cancer often have inflammation and poor oral hygiene. Oral microbiota may play a role in carcinogenesis. Many clinical and epidemiological studies have suggested the existence of relationships between chronic inflammation and infectious diseases. Chronic inflammation is often studied in the context of the mechanisms at work behind the development of cancer. Specifically, pro-inflammatory cytokine interleukin-20 is involved in rheumatoid arthritis, atherosclerosis, osteoporosis and oral cancer (Hsu et al. 2012). The mucosal microenvironment is a specific ecological niche. In this system, bacteria can genetically influence epithelial cells. In the saliva, poor dental status increases carcinogenic acetaldehyde production using ethanol (Homann et al. 2001). The imbalance of the microbiome, followed by translocation via blood circulation, is a major vector for disease progression. In the gut, at the mucosal level, microbial translocation can be explained by the following events, in order: mucosal CD4+ depletion, chronic inflammation, the alteration of the enterocytes in the epithelium and penetration by microorganisms. The mechanism by which microbial translocation causes immune activation is still not well-understood, although the authors 
have concluded that the translocation of periodontopathic bacteria occurs via lymphatic drainage (Amodini Rajakaruna et al. 2012).

\section{Cancer and oral viruses}

A majority of HIV-1 (human immunodeficiency virus) infections worldwide are acquired via mucosal surfaces. The oral transmission of HIV is dependent on the ability of the virus to efficiently cross from one host to the next by traversing mucosal membranes (Wood et al. 2013).

Human papillomaviruses (HPVs) have been found in various types of oral mucosal lesions and are linked to the risk of malignant lesions. Mucosal human papillomaviruses, mostly of the HPV-16 and HPV-18 genotypes, cause head and neck cancers (Kreimer et al. 2005). HPV-16 has been identified in cancers of the tongue.

HPV-16 has also been identified in nonsmokers, nondrinkers (Pintos et al. 2008), oropharyngeal squamous cell carcinoma patients, and specifically in young individuals (Gonzalez-Ramirez et al. 2013). Lin et al. (2010) demonstrated the presence of HPV-11 during the malignant transformation of recurrent respiratory papillomatosis. However, the virus is rarely found in the saliva given a healthy oral mucosa. Many theories have proposed pathways for virus transmission, including perinatal transmission, manual contact and sexual transmission by oral-genital contact (Stanko et al. 2013). Contradictory results have been shown in pediatric acute lymphoblastic leukemia (ALL) with chemotherapy complications (such as oral mucositis (OM)). The presence of HSV and Candida spp. was found to be associated with mucositis in ALL, but no relationship was found between the number of bacterial colony-forming units and the intensity of OM. The type of chemotherapy used could explain these results (de Mendonca et al. 2012).

\section{Gastric, pancreatic, lung cancers and the oral microbiota (Table 3)}

The upper aerodigestive tract is an area of high risk for multiple primary cancers. Periodontal diseases and tooth loss conditions caused by oral bacteria greatly contribute to this risk (Chen et al. 2016). Chronic inflammation, in the presence of alcohol and tobacco, is an established risk factor for 
upper aerodigestive cancer. The microorganisms that compose the oral microbiota greatly differ in abundance, and some have been associated with oral cancer.

Some bacteria (Streptococcus and Treponema) have been linked to various kinds of head and neck cancer (Narikiyo et al. 2004; Shiga 2011). Dental plaque seems to be a reservoir of these pathogens (Sasaki et al. 2005). Several studies based on the pyrosequencing analysis of 16S rRNA genes from the bacterial communities of cancer patients and healthy subjects showed significant differences in their microbiota profiles (Gong et al. 2013; Guerrero-Preston et al. 2016; Hu et al. 2016). The levels of the Streptococcus, Fusobacterium, Abiotrophia, Haemophilus, Prevotella, Tanerella, Agregatibacter, Leptotricha and Neisseria genera have been shown to vary between patients suffering from oral cancers and healthy controls (Gong et al. 2013; Guerrero-Preston et al. 2016; Hu et al. 2016). However, the results between studies are often contradictory, highlighting the need to improve knowledge about the causal relationship between tumor development and oral microbiota.

An association between periodontal diseases and serum albumin concentration was found in head and neck cancers (Maruyama et al. 2012). These results support the presence of an altered oral microbiota in cancer, although longitudinal studies are necessary to determine whether there is a causal relationship.

Typically, oral and esophageal cancers are concomitant with periodontal diseases (Galvão-Moreira and da Cruz 2016). The high salivary counts of Capnocytophaga gingivalis, Prevotella melaninogenica, Streptococcus mitis and Porphyromonas gingivalis may be diagnostic indicators of OSCC (GalvãoMoreira and da Cruz 2016), and Streptoccocus mitis is a biomarker for pancreatic cancer (Farrell et al. 2012). The percentage of gastric and pancreatic cancers associated with periodontal diseases seems to be low (Kim et al. 2009). Other types of cancers (e.g., lung, prostate and hematological) appear to be less consistently associated with periodontal diseases, although the number of studies on this topic remains limited. Nevertheless, a positive link between periodontal diseases and some forms of cancer should be considered (Nugent 2010). 
Gastric carcinoma: Several studies have explored the association between the oral microbiome and gastrointestinal cancers. Chen et al. analyzed the saliva samples of 87 patients with esophageal squamous cell carcinoma, 63 patients with dysplasia and 85 healthy controls. Using $16 \mathrm{~S}$ rRNA gene sequencing, they showed that patients diagnosed with esophageal squamous cell carcinoma exhibited significantly decreased microbial diversity as compared to healthy control and dysplasia patients. Moreover, taxonomic analyses revealed that patients with esophageal squamous cell carcinoma presented a significant decrease in Lautropia, Bulleidia, Catonella, Corynebacterium, Moryella, Peptococcus and Cardiobacterium as compared to heathy controls and patients with dysplasia (Chen et al. 2015).

A small study evaluated the relationship between the salivary microbiota and pancreatic cancer. Farrell et al. analyzed samples from ten patients with pancreatic cancer and ten matched healthy controls using a human oral microbe identification microarray (HUMIM) (Farrell et al. 2012). They showed that 16 taxa changed significantly between cancer patients and controls. However, only six were confirmed using qPCR. Moreover, in an independent validation using new saliva samples from 28 pancreatic cancer patients and 28 healthy controls, only Neisseria elongata and Streptococcus mitis were useful in distinguishing patients with pancreatic cancer from healthy subjects, with an area under the curve value of 0.90 ( $95 \% \mathrm{Cl} 0.78-0.96, \mathrm{p}<0.0001)$, a $96.4 \%$ sensitivity and a $82.1 \%$ specificity (Farrell et al. 2012). Moreover, using an immunoblot array, Michaud et al. evaluated antibodies detected against 25 oral bacteria in the serum of 405 pancreatic cancer patients and 416 healthy controls. They observed that $6 \%$ of the patients with high antibody titres against $P$. gingivalis (>200 ng.ml) had an adjusted OR of 2.14 (95\% Cl: 1.05,-4.36) for pancreatic cancer as compared with those with undetectable or lower levels. Furthermore, in a recent case-control study, Fan et al. assessed the association between the oral microbiome and pancreatic cancer (Fan et al. 2016). They analyzed pre-diagnostic oral wash samples taken from 361 cases of adenocarcinoma of the pancreas and 371 matched controls collected from two prospective cohort studies. Using $16 \mathrm{~S}$ rRNA gene sequencing, they found that Porphyromonas gingivalis and Aggregatibacter actinomycetemcomitans were positively associated with pancreatic cancer, with adjusted ORs of 1.60 
(95\% Cl 1.15-2.22) and 2.20 (95\% Cl 1.16-4.18), respectively. Moreover, they showed that Fusobacteria and Leptotrichia were negatively associated with pancreatic cancer, with ORs of 0.94 (95\% Cl 0.89-0.99) and 0.87 (95\% Cl 0.79-0.95), respectively (Fan et al. 2016).

Helicobacter pylori is often associated with peptic and gastric cancers. This species is associated with esophageal adenocarcinoma and esophageal squamous cell carcinoma. Helicobacter infection favors apoptosis, activates cyclooxygenase and inhibits heat shock protein (Targosz et al. 2012). Streptococcus anginosus may be associated with esophageal cancer, as well as head and neck cancer. Periodontitis often represents a permanent reservoir of this bacterium (Souto and Colombo 2008).

Pancreatic cancer: Several studies have reported a link between oral infection and an increased risk of pancreatic cancer. Variations in the biomarkers of the salivary microbiota may play a role in pancreatic pathologies (Torres et al. 2015). Several potential bacterial biomarkers have been identified: Neisseria elongate, Streptococcus mitis, Porphyromonas gingivalis and Agregatibacter actinomycetemcomitans (Fan et al. 2016). More recently, Fusobacterium species of the oral bacterial group were detected in pancreatic cancer tissue and may be a prognostic biomarker of this pathology (Mitshuhashi et al. 2015). Fusobacterium spp are pleomorphic and seem to be a symptom of clinically significant acute or chronic illness, rather than implying pathogen-specific therapeutic challenges for clinicians (Johannesen et al. 2016).

Lung cancer: Lung cancer is the greatest cause of mortality worldwide. A study on the salivary transcriptomes of lung cancer patients pre-validated seven biomarkers of the disease. Instead of the lung, the buccal (cheek) mucosa has been suggested as an excellent surrogate site in the field of injury (Radosevich et al. 2014). Among bacteria, the relationships between Neisseria, Streptococcus and Porphyromonas and lung cancer have been established, along with clearly significant associations between salivary Capnocytophaga and Veillonella and lung cancer (including squamous cell carcinoma and adenocarcinoma) (Yan et al. 2015). 


\section{Host side}

The normal healthy state of the oral mucosal cavity is a state of balance between various organisms and the host. The oral microbiota is now understood as an organ whose mechanisms closely match those of the gut microbiota ecosystem. The stability of the microbiota increases with probiotics and prebiotics (Zaura et al. 2014).

Many antimicrobial peptides are expressed by epithelial cells, helping to preserve the equilibrium between the constituents of the microbiota. In addition, these molecules have specific properties and play a role in the immune system (Bowdish et al. 2005), for example, epithelial antimicrobial peptides (AMPs) have targets within the microbiota and in cancer neck tissues. In healthy patients, the homeostasis of the constituents of the microbiota prevents aggression on the part of pathogens. Several families of antimicrobial peptides are described, and they are specifically designed to kill or inactivate microorganisms that come in contact with epithelial surfaces (Zasloff 2002). AMPs are present on the mucosa and in saliva and are the front line of defense against bacteria, viruses and fungi (Lai et al. 2009). Furthermore, the innate immune receptors identify bacterially conserved microbe-associated molecular patterns (MAMPs) (Medzhitov and Janeway 2000). This mechanism is used by the innate immune system to differentiate pathogenic and non-pathogenic bacteria. This distinction between pathogenic and innocuous bacteria remains the main concern of many research teams. Parameters such as structure, expression, virulence factors and invasive properties are being investigated. Furthermore, the infection can be influenced by the genetic variations of the host, which can result in defective peptides (Kalus et al. 2009). In the intestine, AMPs are produced by epithelial cells.

A constant cross-talk takes place between these cells, which are present in the saliva, and the commensal microorganisms to maintain the homeostasis of the gut. The perturbation of AMP production plays a major role in the etiology of the inflammatory Gl-tract, underscoring the importance of gut microbial homeostasis (Guani-Guerra et al. 2010). 


\section{Biomarkers for early cancer detection (Table 4)}

Multiple studies have shown that the oral microbiota overlaps with the gastrointestinal tract microbiota and that there are many avenues for the dissemination of bacteria within the body (Alvires-Jimenez et al. 2014; Prasad et al. 2016). In 1994, Lamster et al. reported on the potential relationships between periodontal pathologies, the oral microbiota and host response (Lamster et al. 1994).

The $\beta$-glucuronidase ( $\beta G$ ) level in the saliva may be a quantitative marker of oral inflammation (Lamster et al. 2003). Other biomarkers exist for rheumatoid arthritis (Mirrielees et al. 2010).

Saliva is an abundant and accessible biofluid (Sivadasan et al. 2015; Javaid et al. 2016). However, recently, a new approach integrating both saliva and tumor tissue metabolomics will be useful in understanding the origin of salivary metabolites in oral cancer patients. Oral cancer can be detected via four mRNA markers of cell-free saliva using microarray technology (Li et al. 2004). Despite the ability of the identified biomarkers to discriminate oral cancers from controls, no significant difference in disease stages and histological types were identified, which prevents the use of these markers as screening tools with which to evaluate all oral cancers (Ishikawa et al. 2016).

Recent advances in salivary cancer diagnostics have enabled wearable bioelectronics, with in vivo monitoring detection of target analytes. Two types of wearable mouth-guard biosensors have been developed for the continuous monitoring of cancer biomarkers, such lactate and uric acid, in the saliva. This mouth-guard biosensor, used for the real-time detection of salivary metabolite via Bluetooth wireless transmission, has opened a new era of in vivo salivary diagnostic devices (Kim et al. 2015). However, no established publication in this area describes methods and techniques with which to detect DNA and RNA in real time (Mishra et al. 2016).

The oral complications of cancer treatment may have selective effects related to oral care, and these effects may be important for health maintenance. The control of biofilms via hygienic procedures is necessary to limit the installation and development of the oral microbiome. However, predicting the 
risk of adverse oral outcomes is difficult. In this regard, periodontal treatments have been shown to induce systemic changes in several inflammatory markers.

\section{Radiotherapy}

During radiation therapy with only $20 \mathrm{~Gy}$, approximately $80 \%$ of salivary function is lost, and above 30 Gy, permanent damages are sustained. Changes occur in antibacterial properties, with consequent alterations in the oral microbiome, and the $\mathrm{pH}$ of the saliva decreases to about 5 . The levels of acidogenic and cariogenic bacterial species, such as Streptococcus mutants, Actinomyces and Lactobacillus, increase, while the concentrations of Neisseria, Fusobacterium and Streptococcus sanguis decrease (de Barros da Cunha et al. 2015).

In 2013, another study was performed on eight irradiated patients with head and neck cancers. The variety of organisms in the oral microbiota was assessed using 16S rDNA 454 pyrosequencing (V1-V3) and UniFrac metrics studies. In these irradiated patients, there was an increase in the occurrence caries, which was related to three genera (Streptococcus, Veillonella and Actinomyces) (Hu et al, 2013). After irradiation (head and neck radiotherapy), the level of S. sanguis decreased, whereas those of Streptococcus mitis and S. salivarius increased. Furthermore, the impact of conventional radiotherapy differs from that of intensity modulated radiotherapy (IMRT), which limits the negative effect of irradiation on the tissue near the tumor. Thus, in IMRT patients, a reduction in the severity of hyposalivation was observed, and in this situation, the temporal stability of the oral ecosystem was found to be significantly beneficial (Shao et al. 2011).

When patients with head and neck cancer undergo radiotherapy, the proliferation of oral yeast (genus Candida) is induced. A study of 92 patients showed that this proliferation involved a diversity of Candida, with the noalbicans species prevailing (Basu et al. 2012). Another study that examined 36 patients with tongue carcinoma previous to antitumor therapy revealed oral dysbiosis. The same patients, after preoperative radiotherapy and before surgery saw an increase in the pathogenic potential of selected microflora. As a precautionary measure, patients must establish and maintain 
oral hygiene before and after treatments to prevent postoperative complications (Lebedev et al. 2015).

The differential diagnosis of osteoradionecrosis (ORN), separating it from a relapse of malignancy or an inflammation-driven infection, is necessary. There is a significant overlap in the standard uptake values among patients with ORN and those with tumor recurrence.

Oral mucositis: Mucositis is a medical condition characterized by inflammatory lesions located within the oral and gastrointestinal mucosa. Many etiologies are attributed to mucositis, including infectious disease, immune deficiency, medications and high-dose cancer therapy. In addition, one study suggests a potential relationship between coagulase-negative staphylococci and oral mucositis in patients with acute lymphoblastic leukemia undergoing antineoplastic chemotherapy (Soares et al. 2011).

The risks associated with a combination of chemotherapy and radiotherapy may influence the gravity of oral mucositis (OM). In these conditions, the management of $\mathrm{OM}$ is an important challenge, with the risk of bloodstream inoculation being associated with the degree of degradation of the epithelial and connective tissue and with marrow suppression. Mouthwash has been recommended to prevent $\mathrm{OM}$ in patients receiving more than $50 \mathrm{~Gy}$ of radiotherapy without concomitant chemotherapy (Vasconcelos et al. 2016).

Among methods used to prevent chemotherapy- and/or radiotherapy-induced mucositis, maintaining oral hygiene is of utmost importance, including an oral care protocol (brushing, flossing, dental visits before and during the treatment and the usage of bland mouth-washes) (Hashemi et al. 2015). The use of chlorhexidine digluconate $(0,05-0,2 \%)$ as an antimicrobial rinse may be beneficial in terms of reducing oral microbial load and the chances of secondary infection. However, chlorhexidine is not recommended for the prevention of oral mucositis in patients with solid tumours of the head and neck and those who are undergoing radiotherapy (Zhu et al. 2016).

For the prevention and relief of oral mucositis, a palliative effect is sought in order to reduce the pain, duration and severity of the pathology. All experts advise the use of frequent mouthwashes, in addition to $0,9 \%$ saline and sodium bicarbonate rinses; the patient should rinse with at least 8-12 
fluid ounces in mouthful-sized portions, with expectoration until completion (Turner et al. 2013). It was also mentioned that honey, which is used in some parts of the world of this purpose, may be an effective and feasible option for preventing mucositis (Zhu et al. 2016).

Many studies have proposed various predictive biomarkers for the severity of OM in patients after radiotherapy (Loo et al. 2013). Early results suggest that a marker of blood lymphocytes, gamma$\mathrm{H} 2 \mathrm{AX}$, correlates with the degree of OM severity before radiotherapy. In an interesting study on the consequences of breast cancer, patients were shown to experience long-term elevations of serum T4 (thyroxin) and T3 (triiodothyronine) levels. The findings support the idea that thyroid function is damaged in breast cancer patients with post-traumatic stress disorder; elevated T3 and T4 levels, together with ulcerative OM, could be indicative of the emotional status of these patients (Loo et al. 2013).

The use of palifermin, cryotherapy and low-power lasers (Peterson et al .2013, Chaveli-López and Bagán-Sebastián 2016) was also tested as a possible method of preventing oral mucositis in patients receiving specific types of chemotherapy. This technique is also used as a treatment to reduce inflammation in patients treated with edatrexate. However, based on the information gathered in this review of the literature, the current topical treatment of mucositis-related pain is based on empiricism and not on scientific evidence. One significant problem is the risk of malnutrition after a high dose of chemoradiotherapy due to problems with swallowing as a result of OM. This problem can be avoided via early enteral nutrition. The use of mouth rinses, such as Caphosol $\mathrm{R}$ (supersaturated $\mathrm{Ca}^{2+} / \mathrm{PO}_{4}$ oral rinse), in patients with high-dose cancer therapy has been deemed efficacious in reducing the pain and grade of mucositis. However, it is not evident that Caphosol use can counter the debilitating effects of OM (Lambrecht et al. 2013). Specific adjuvant treatments, such as irsogladine maleate (IM) treatment, have been successfully tested for use in OM (Nomura et al. 2013).

Oral management is necessary to reduce the occurrence of oral mucositis resulting from allogenic or autologous hematopoietic stem cell therapy (HSCT), radiotherapy and chemotherapy. Twice-daily 
brushing can be used in limiting the accumulation of plaque. Control over the initial stage of accumulation, that is, the formation of biofilm is the basis of therapy.

\section{Conclusion}

The accumulated evidence suggests physiologic relationships between inflammatory and immune diseases via the oral cavity. Species-level identification may be insufficient to understand the link between microbiota and cancer.

Nevertheless, the genes and proteins of all the microbial species that colonize the digestive tract constitute an area of research in the field of evolutionary biology. The analysis of these genes sends us back to an unknown universe: in total, three million genes in microbial species remain to be identified, making the collective microbial genome much more complex than the human genome. The knowledge of these microbial species is rapidly developing, and further understanding will require metagenomic and proteomic studies. These discoveries in the microbiology of infectious diseases will have an impact on the identification of known and new microorganisms involved in chronic diseases such as cancer (Kipanyula et al. 2013). 


\section{References :}

Aas, J.A., Paster, B.J., Stokes, L.N., Olsen, I., Dewhirst, F.E. 2005. Defining the normal bacterial flora of the oral cavity. J. Clin. Microbiol. 43(11) : 5721-5732.

Ahn, J., Chen, C.Y., Hayes, R.B. 2012. Oral microbiome and oral and gastrointestinal cancer risk [en ligne]. Cancer Causes Control. 23(3):399-404. doi: 10.1007/s10552-011-9892-7.

Alvires-Jimenez, F., Vazquez-Jimenez, F., Medrano-Guzman, R., Mantilla, A., Torres, J. 2014. Stomach microbiota composition varies between patients with non-atrophic gastritis and patients with intestinal type of gastric cancer [en ligne]. Sci. Rep. 4 : 4202 . doi: 10.1038/srep04202.

Amodini Rajakaruna, G., Umeda, M., Uchida, K., Furukawa, A., Yuan, B., Suzuki, Y. et al. 2012. Possible translocation of periodontal pathogens into the lymph nodes draining the oral cavity [en ligne]. J. Microbiol. Seoul Korea 50(5) : 827-836. doi: 10.1007/s12275-012-2030-8.

Bajaj, J.S., Betrapally, N.S., Hylemon, P.B., Heuman, D.M., Daita, K., White, M.B. et al. 2015. Salivary microbiota reflects changes in gut microbiota in cirrhosis with hepatic encephalopathy [en ligne]. Hepatology 62(4) : 1260-1271. doi: 10.1002/hep.27819.

Bars, P.L., Soueidan, A. 2012. Distribution Patterns of E-Cadherin, Type VII Collagen and Fibronectin in Denture-Related Stomatitis: A Preliminary Study [en ligne]. Open Dent. J. 6 : 14-22. doi: $10.2174 / 1874210601206010014$.

Bassis, C.M., Tang, A.L., Young, V.B., Pynnonen, M.A. 2014. The nasal cavity microbiota of healthy adults [en ligne]. Microbiome $2: 27$. doi: 10.1186/2049-2618-2-27.

Bassis, C.M., Erb-Downward, J.R., Dickson, R.P., Freeman, C.M., Schmidt, T.M., Young, V.B., Beck, J.M., Curtis, J.L., Huffnagle, G.B. 2015. Analysis of the upper respiratory tract microbiotas as source of lung and gastric microbiotas in healthy individuals [en ligne]. MBio 6(2) : e00037-15. doi:10 $.1128 / \mathrm{mBio} .00037-15$.

Basu, T., Laskar, S.G., Gupta, T., Budrukkar, A., Murthy, V., Agarwal, J.P. 2012. Toxicity with radiotherapy for oral cancers and its management: a practical approach [en ligne]. J. Cancer Res. Ther. 8(Suppl 1) : S72-S84. doi: 10.4103/0973-1482.92219. 
Bogaert, D., Keijser, B., Huse, S., Rossen, J., Veenhoven, R., van Gils, E. et al. 2011. Variability and diversity of nasopharyngeal microbiota in children : a metagenomic analysis [en ligne]. Plos One 6(2) : e17035. doi: 10.1371/journal.pone.0017035.

Bowdish, D.M., Davidson, D.J., Scott, M.G., Hancock, R.E. 2005. Immunomodulatory activities of small host defense peptides. Antimicrob. Agents Chemother. 49(5) : 1727-1732.

Chaveli-López, B., Bagán-Sebastián, J. 2016. Treatment of oral mucositis due to chemotherapy [en ligne]. J. Clin. Exp. Dent. 8(2) : e201-e209. doi: 10.4317/jced.52917.

Chen, L.J., Tsai, H.T., Chen, W.J., Hsieh, C.Y., Wang, P.C., Chen, C.S. et al. 2012. In vitro antagonistic growth effects of Lactobacillus fermentum and lactobacillus salivarius and their fermentative broth on periodontal pathogens [en ligne]. Braz. J. Microbiol. 43(4) : 1376-1384. doi: 10.1590/S1517838220120004000019.

Chen, X., Winckler, B., Lu, M., Cheng, H., Yuan, Z., Yang, Y. et al. 2015. Oral Microbiota and Risk for Esophageal Squamous Cell Carcinoma in a High-Risk Area of China [en ligne]. PLoS One. 10(12) : e0143603. doi: 10.1371/journal.pone.0143603.

Chen, X., Yuan, Z., Lu, M., Zhang, Y., Jin, L., Ye, W. 2016. Poor oral health is associated with an increased risk of esophageal squamous cell carcinoma - a population-based case-control study in China [en ligne]. Int. J. Cancer. doi: 10.1002/ijc.30484.

Cho, I., Blaser, M.J. 2012. The human microbiome: at the interface of health and disease [en ligne]. Nat. Rev. Genet. 13(4) : 260-270. doi: 10.1038/nrg3182.

Collins, L.M., Dawes, C. 1987. The surface area of the adult human mouth and thickness of the salivary film covering the teeth and oral mucosa. J. Dent. Res. 66(8) : 1300-1302.

Costello, E.K., Lauber, C.L., Hamady, M., Fierer, N., Gordon, J.I., Knight, R. 2009. Bacterial community variation in human body habitats across space and time [en ligne]. Science 326(5960) : 1694-1697. doi: 10.1126/science.1177486.

de Barros da Cunha, S.R., Ramos, P.A., Nesrallah, A.C., Parahyba, C.J., Fregnani, E.R., Aranha, A.C. 2015. The effects of ionizing radiation on the oral cavity. J. Contemp. Dent. Pract. 16(8) : 679-687. 
de Freitas, E.M., Nobre, S.A., Pires, M.B., Faria, R.V., Batista, A.U., Bonan, P.R. 2013. Oral Candida species in head and neck cancer patients treated by radiotherapy [en ligne]. Auris Nasus Larynx 40(4) : 400-404. doi: 10.1016/j.anl.2012.11.011.

de Mendonça, R.M., de Araujo, M., Levy, C.E., Morari, J., Silva, R.A., Yunes, J.A. et al. 2012. Prospective evaluation of HSV, Candida spp., and oral bacteria on the severity of oral mucositis in pediatric acute lymphoblastic leukemia [en ligne]. Support Care Cancer 20(5) : 1101-1107. doi: 10.1007/s00520-011-1190-0.

Deshpande, K., Jain, A., Sharma, R., Prashar, S., Jain, R. 2010. Diabetes and periodontitis [en ligne]. J. Indian Soc. Periodontol. 14(4) : 207-212. doi: 10.4103/0972-124X.76917.

DiGiulio, D.B., Callahan, B.J., McMurdie, P.J., Costello, E.K., Lyell, D.J., Robaczewska, A. et al. 2015. Temporal and spatial variation of the human microbiota during pregnancy [en ligne]. Proc. Natl. Acad. Sci. USA 112(35) : 11060-11065. doi: 10.1073/pnas.1502875112.

Fabian, M.C., Pachev, G. 2008. Otolaryngology training during paediatric residency: A survey of paediatricians in Canada. Paediatr. Child Health 13(6) : 493-498.

Fan, X., Alekseyenko, A.V., Wu, J., Peters, B.A., Jacobs, E.J., Gapstur, S.M. et al. 2016. Human Oral Microbiome and Prospective Risk for Pancreatic Cancer: A Population-Based Nested Case-Control Study [en ligne]. Gut. doi: 10.1136/gutjnl-2016-312580.

Farag, Y.M., Gaballa, M.R. 2011. Diabesity: an overview of a rising epidemic [en ligne]. Nephrol. Dial. Transplant. 26(1) : 28-35. doi: 10.1093/ndt/gfq576.

Farrell, J.J., Zhang, L., Zhou, H., Chia, D., Elashoff, D., Akin, D. et al. 2012. Variations of oral microbiota are associated with pancreatic diseases including pancreatic cancer [en ligne]. Gut 61(4) : 582-588. doi: 10.1136/gutjnl-2011-300784.

Flores, G.E., Caporaso, J.G., Henley, J.B., Rideout, J.R., Domogala, D., Chase, J. et al. 2014. Temporal variability is a personalized feature of the human microbiome [en ligne]. Genome Biol. 15(12) : 531. doi: 10.1186/s13059-014-0531-y.

Francescone, R., Hou, V., Grivennikov, S.I. 2014. Microbiome, inflammation, and cancer [en ligne]. Cancer J. 20(3) : 181-189. doi: 10.1097/PPO.0000000000000048. 
Kim, T.K., Thomas, S.M., Ho, M., Sharma, S., Reich, C.I., Frank, J.A. et al. 2009. Heterogeneity of vaginal microbial communities within individuals [en ligne]. J. Clin. Microbiol. 47(4) : 1181-1189. doi: 10.1128/JCM.00854-08.

Galvão-Moreira, L.V., da Cruz, M.C. 2016. Oral microbiome, periodontitis and risk of head and neck cancer [en ligne]. Oral Oncol. 53: 17-19. doi: 10.1016/j.oraloncology.2015.11.013.

Gong, H.L., Shi, Y., Zhou, L., Wu, C.P., Cao, P.Y., Tao, L. et al. (2013). The Composition of Microbiome in Larynx and the Throat Biodiversity between Laryngeal Squamous Cell Carcinoma Patients and Control Population [en ligne]. PloS One 8(6) : e66476. doi: 10.1371/journal.pone.0066476.

Gonzalez-Ramirez, I., Irigoyen-Camacho, M.E., Ramirez-Amador, V., Lizano-Soberon, M., CarrilloGarcia, A., Garcia-Carranca, A. et al. (2013). Association between age and high-risk human papilloma virus in Mexican oral cancer patients [en ligne]. Oral Dis. 19(8) : 796-804. doi: 10.1111/odi.12071.

Guani-Guerra, E., Santos-Mendoza, T., Lugo-Reyes, S.O., Teran, L.M. 2010. Antimicrobial peptides: general overview and clinical implications in human health and disease [en ligne]. Clin. Immunol. 135(1) : 1-11. doi: 10.1016/j.clim.2009.12.004.

Guerrero-Preston, R.F., Godoy-Vitorino, F., Jedlicka, A., Rodríguez-Hilario, A., González, H., Bondy, J. et al. 2016. 16S rRNA Amplicon Sequencing Identifies Microbiota Associated with Oral Cancer, Human Papilloma Virus Infection and Surgical Treatment [en ligne]. Oncotarget: 1-15. doi: 10.18632/oncotarget.9710.

Haiser, H.J., Turnbaugh, P.J. 2012. Is it time for a metagenomic basis of therapeutics? [en ligne]. Science 336(6086) : 1253-1255. doi: 10.1126/science.1224396.

Hashemi, A., Bahrololoumi, Z., Khaksar, Y., Saffarzadeh, N., Neamatzade, H., Foroughi, E. 2015. Mouth-rinses for the prevention of chemotherapy induced oral mucositis in children: a systematic review. Iran J. Ped. Hematol. Oncol. 15(2) : 106-112.

Holt, S.C., Ebersole, J.L. 2005. Porphyromonas gingivalis, Treponema denticola, and Tannerella forsythia: the "red complex ", a prototype polybacterial pathogenic consortium in periodontitis. Periodontol. $200038:$ 72-122. 
Homann, N., Tillonen, J., Rintamäki, H., Salaspuro, M., Lindqvist, C., Meurman, J.H. 2001. Poor dental status increases acetaldehyde production from ethanol in saliva: a possible link to increased oral cancer risk among heavy drinkers. Oral Oncol. 37(2) : 153-158.

Horz, H.P., Conrads, G. 2011. Methanogenic Archaea and oral infections - ways to unravel the black box [en ligne]. J. Oral. Microbiol. 3. doi: 10.3402/jom.v3i0.5940.

Hsu, Y.H., Wei, C.C., Shieh, D.B., Chan, C.H., Chang, M.S. 2012. Anti-IL-20 monoclonal antibody alleviates inflammation in oral cancer and suppresses tumor growth [en ligne]. Mol. Cancer Res. 10(11) : 1430-1439. doi: 10.1158/1541-7786.MCR-12-0276.

Hu, Y.J., Wang, Q., Jiang, Y.T., Ma, R., Xia, W.W., Tang, Z.S. et al. 2013. Characterization of oral bacterial diversity of irradiated patients by high-throughput sequencing [en ligne]. Int. J. Oral Sci. 5(1) :21-25. doi: 10.1038/ijos.2013.15.

Hu, X., Zhang, Q., Hua, H., Chen, F. 2016. Changes in the Salivary Microbiota of Oral Leukoplakia and Oral Cancer [en ligne]. Oral Oncol. 56 : e6-8. doi:10.1016/j.oraloncology.2016.03.007

Human Microbiome Project Consortium. 2012. Structure, function and diversity of the healthy human microbiome [en ligne]. Nature 486 (7402) : 207-214. doi: 10.1038/nature11234.

Huynh, H.T., Verneau, J., Levasseur, A., Drancourt, M., Aboudharam, G. 2016. Bacteria and archaea paleomicrobiology of the dental calculus: a review [en ligne]. Mol. Oral Microbiol. 31(3) :234-242. doi: 10.1111/omi.12118.

Ishikawa, S., Sugimoto, M., Kitabatake, K., Sugano, A., Nakamura, M., Kaneko, M. et al. 2016. Identification of salivary metabolomics biomarkers for oral cancer screening [en ligne]. Sci Rep. 6 : 31520. doi:10.1038/srep 31520.

Javaid, M.A., Ahmed A.S., Durand, R., Tran, S.D. 2016. Saliva as a diagnostic tool for oral and systemic diseases. J Oral Biol Craniofac Res. 6(1) : 66-75.

Jimenez Torres, N.V., Romero Crespo, I., Ballester Solaz, M., Albert Mari, A., Jimenez Arenas, V. 2009. Antineoplastic oral agents and drug-nutrient interactions: a systematic review [en ligne]. Nutr. Hosp. $24(3): 260-272$. 
Johannesen, K., Dessau, R., Heltberg, O., Bodtger, U. 2016. Bad news itself or just the messenger? The high mortality of Fusobacterium spp. infections is related to disseminated malignancy and other comorbidities [en ligne]. Eur. Clin. Respir. J. 3 : 30287. doi: 10.3402/ecrj.v3.30287.

Kalus, A.A., Fredericks, L.P., Hacker, B.M., Dommisch, H., Presland, R.B., Kimball, J.R. et al. 2009. Association of a genetic polymorphism (-44 C/G SNP) in the human DEFB1 gene with expression and inducibility of multiple beta-defensins in gingival keratinocytes [en ligne]. BMC Oral Health 9:21. doi: $10.1186 / 1472-6831-9-21$

Kanady, J.A., Aruni, A.W., Ninnis, J.R., Hopper, A.O., Blood, J.D., Byrd, B.L. et al. 2012. Nitrate reductase activity of bacteria in saliva of term and preterm infants [en ligne]. Nitric Oxide 27(4) : 193200. doi: 10.1016/j.niox.2012.07.004.

Keijser, B.J., Zaura, E., Huse, S.M., van der Vossen, J.M., Schuren, F.H., Montijn, R.C. et al. 2008. Pyrosequencing analysis of the oral microflora of healthy adults. J. Dent. Res. 87(11) : 1016-1020.

Kim, J.J., Kim, C.J., Camargo, P.M. 2013. Salivary biomarkers in the diagnosis of periodontal diseases. J. Calif. Dent. Assoc. 41(2) : 119-124.

Kim, J., Imani, S., de Araujo, W.R., Warchall, J., Valdés-Ramírez, G., Paixão, T.R. et al. 2015. Wearable salivary uric acid mouthguard biosensor with integrated wireless electronics [en ligne]. Biosens. Bioelectron. 74 : 1061-1068. doi: 10.1016/j.bios.2015.07.039.

Kipanyula, M.J., Seke Etet, P.F., Vecchio, L., Farahna, M., Nukenine, E.N., Nwabo Kamdje, A.H. 2013. Signaling pathways bridging microbial-triggered inflammation and cancer [en ligne]. Cell Signal 25(2) : 403-416. doi: 10.1016/j.cellsig.2012.10.014.

Kistler, J.O., Arirachakaran, P., Poovorawan, Y., Dahlén, G., Wade, W.G. 2015. The oral microbiome in human immunodeficiency virus (HIV)-positive individuals [en ligne]. J. Med. Microbiol. 64(9) : 10941101. doi: $10.1099 / \mathrm{jmm} \cdot 0.000128$.

Kreimer, A.R., Clifford, G.M., Boyle, P., Franceschi, S. 2005. Human papillomavirus types in head and neck squamous cell carcinomas worldwide: a systematic review. Cancer Epidemiol. Biomarkers Prev. 14(2):467-475. 
Lai, Y., Gallo, R.L. 2009. AMPed up immunity: how antimicrobial peptides have multiple roles in immune defense [en ligne]. Trends Immunol. 30(3) : 131-141. doi: 10.1016/j.it.2008.12.003.

Laidi, F., Bouziane, A., Errachid, A., Zaoui, F. 2016. Usefulness of Salivary and Serum Auto-antibodies Against Tumor Biomarkers HER2 and MUC1 in Breast Cancer Screening. Asian Pac. J. Cancer Prev. $17(1): 335-339$.

Lambrecht, M., Mercier, C., Geussens, Y., Nuyts, S. 2013. The effect of a supersaturated calcium phosphate mouth rinse on the development of oral mucositis in head and neck cancer patients treated with (chemo)radiation: a single-center, randomized, prospective study of a calcium phosphate mouth rinse + standard of care versus standard of care [en ligne]. Support Care Cancer 21(10) : 2663-2670. doi: 10.1007/s00520-013-1829-0.

Lamster, I.B., Smith, Q.T., Celenti, R.S., Singer, R.E., Grbic, J.T. 1994. Development of a risk profile for periodontal disease: microbial and host response factors. J. Periodontol. 65(5 Suppl) : 511-520.

Lamster, I.B., Kaufman, E., Grbic, J.T., Winston, L.J., Singer, R.E. 2003. Beta-glucuronidase activity in saliva: relationship to clinical periodontal parameters. J. Periodontol. 74(3) : 353-359.

Lebedev, S.N., Bogatov, V.V., Chervinets, V.M., Chervinets, I.V., Chervinets, A.V., Troshin, A.V. 2015. Microbiocenosis of major biotopes of the oral cavity in patients with tongue carcinoma during complex treatment. Stomatologiia 94(1) : 30-34.

Leishman, S.J., Ford, P.J., Do, H.L., Palmer, J.E., Heng, N.C., West, M.J. et al. 2012. Periodontal pathogen load and increased antibody response to heat shock protein 60 in patients with cardiovascular disease [en ligne]. J. Clin. Periodontol. 39(10) : 923-930. doi: 10.1111/j.1600051X.2012.01934.x

Lemon, K.P., Klepac-Ceraj, V., Schiffer, H.K., Brodie, E.L., Lynch, S.V., Kolter, R. 2010. Comparative analyses of the bacterial microbiota of the human nostril and oropharynx [en ligne]. MBio. 1(3) : e00129-10. doi: 10.1128/mBio.00129-10.

Li, Y., Zhou, X., St John, M.A., Wong, D.T. 2004. RNA profiling of cell-free saliva using microarray technology. J. Dent. Res. 83(3) : 199-203. 
Lin, H.W., Richmon, J.D., Emerick, K.S., de Venecia, R.K., Zeitels, S.M., Faquin, W.C. et al. 2010. Malignant transformation of a highly aggressive human papillomavirus type 11-associated 664 recurrent respiratory papillomatosis [en ligne]. Am. J. Otolaryngol. 31(4) : 291-296. doi: 10.1016/j.amjoto.2009.02.019.

Loo, W.T., Liu, Q., Yip, M.C., Wang, M., Chow, L.W., Cheung, M.N. et al. 2013. Status of oral ulcerative mucositis and biomarkers to monitor posttraumatic stress disorder effects in breast cancer patients [en ligne]. Int. J. Biol. Markers 28(2) : 168-173. doi: 10.5301/jbm.5000025.

Love, D.N., Bailey, G.D., Collings, S., Briscoe, D.A. 1992. Description of Porphyromonas circumdentaria sp. nov. and reassignment of Bacteroides salivosus (Love, Johnson, Jones, and Calverley 1987) as Porphyromonas (Shah and Collins 1988) salivosa comb. nov. Int. J. Syst. Bacteriol. 42(3) : 434-438.

Lozupone, C.A., Stombaugh, J.I., Gordon, J.I., Jansson, J.K., Knight, R. 2012. Diversity, stability and resilience of the human gut microbiota. Nature 489(7415) : 220-230.

Mark Welch, J.L., Utter, D.R., Rossetti, B.J., Mark Welch, D.B., Eren, A.M., Borisy, G.G. 2014. Dynamics of tongue microbial communities with single-nucleotide resolution using oligotyping [en ligne]. Front. Microbiol. 5 : 568. doi: 10.3389/fmicb.2014.00568.

Maruyama, K., Asai, J., li, M., Thorne, T., Losordo, D.W., D’Amore, P.A. 2007. Decreased macrophage number and activation lead to reduced lymphatic vessel formation and contribute to impaired diabetic wound healing. Am. J. Pathol. 170(4) : 1178-1191.

Maruyama, T., Yamanaka, R., Yokoi, A., Ekuni, D., Tomofuji, T., Mizukawa, N. et al. 2012. Relationship between serum albumin concentration and periodontal condition in patients with head and neck cancer [en ligne]. J. Periodontol. 83(9) : 1110-1115. doi: 10.1902/jop.2011.110536.

Medzhitov, R., Janeway, C.Jr. 2000. Innate immune recognition: mechanisms and pathways. Immunol. Rev. 173 : 89-97.

Meurman, J.H., Grönroos, L. 2010. Oral and dental health care of oral cancer patients: hyposalivation, caries and infections [en ligne]. Oral Oncol. 46(6) : 464-467. doi: 10.1016/j.oraloncology.2010.02.025. 
Meyer, M.S., Joshipura, K., Giovannucci, E., Michaud, D.S. 2008. A review of the relationship between tooth loss, periodontal disease, and cancer [en ligne]. Cancer Causes Control. 19(9) : 895-907. doi: 10.1007/s10552-008-9163-4.

Michaud, D.S., Izard, J., Wilhelm-Benartzi, C.S., You, D.H., Grote, V.A., Tjønneland, A. et al. 2013. Plasma antibodies to oral bacteria and risk of pancreatic cancer in a large European prospective cohort study [en ligne]. Gut. 62(12) : 1764-1770. doi: 10.1136/gutjnl-2012-303006.

Michelet, X., Legouis, R. 2012. Autophagy in endosomal mutants: Desperately seeking to survive. Worm. 1(4) : 216-220.

Mima, K., Sukawa, Y., Nishihara, R., Qian, Z.R., Yamauchi, M., Inamura, K. et al. 2015. Fusobacterium nucleatum and T Cells in Colorectal Carcinoma [en ligne]. JAMA Oncol. 1(5):653-61. doi: 10.1001/jamaoncol.2015.1377.

Mirrielees, J., Crofford, L.J., Lin, Y., Kryscio, R.J., Dawson, D.R. 3rd, Ebersole, J.L. et al. 2010. Rheumatoid arthritis and salivary biomarkers of periodontal disease [en ligne]. J. Clin. Periodontol. 37(12) : 1068-1074. doi: 10.1111/j.1600-051X.2010.01625.x.

Mishra, S., Saadat, D., Kwon, O., Lee, Y., Choi, W.S., Kim, J.H. et al. 2016 Recent advances in salivary cancer diagnostics by biosensors and electronics [en ligne]. Biosens. Bioelectron; 81 : 181-197. doi: 10.1016/j.bios.2016.02.040.

Mitsuhashi, K., Nosho, K., Sukawa, Y., Matsunaga, Y., Ito, M., Kurihara, H. et al. 2015. Association of Fusobacterium species in pancreatic cancer tissues with molecular features and prognosis. Oncotarget 6(9) : 7209-7220.

Momen-Heravi, F., Trachtenberg, A.J., Kuo, W.P., Cheng, Y.S. 2014. Genomewide Study of Salivary MicroRNAs for Detection of Oral Cancer. J. Dent. Res. 93(7 Suppl) :86S-93S.

Monteiro, A.M., Jardini, M.A., Giampaoli, V., Alves, S., Figueiredo Neto, A.M., Gidlund, M. 2012. Measurement of the nonlinear optical response of low-density lipoprotein solutions from patients with periodontitis before and after periodontal treatment: evaluation of cardiovascular risk markers. J. Biomed. Opt. 17(11) : 115004. 
Morita, E., Narikiyo, M., Nishimura, E., Yano, A., Tanabe, C., Sasaki, H. et al. 2004. Molecular analysis of age-related changes of Streptococcus anginosus group and Streptococcus mitis in saliva. Oral Microbiol. Immunol. 19(6) : 386-389.

Mulcahy, M.E., McLoughlin, R.M. 2016. Host-bacterial crosstalk Staphylococcus aureus nasal colonization. Trends Microbiol. 24(11) : 872-886.

Nadell, C.D., Xavier, J.B., Foster, K.R. 2009. The sociobiology of biofilms [en ligne]. FEMS Microbiol. Rev. 33(1) : 206-224. doi: 10.1111/j.1574-6976.2008.00150.x.

Narikiyo, M., Tanabe, C., Yamada, Y., Igaki, H., Tachimori, Y., Kato, H. et al. 2004. Frequent and preferential infection of Treponema denticola, Streptococcus mitis, and Streptococcus anginosus in esophageal cancers [en ligne]. Cancer Sci. 95(7) : 569-574.

Nasidze, I., Li, J., Quinque, D., Tang, K., Stoneking, M. 2009. Global diversity in the human salivary microbiome [en ligne]. Genome Res. 19(4) : 636-643. doi: 10.1101/gr.084616.108.

Nasidze, I., Quinque, D., Li, J., Li, M., Tang, K., Stoneking, M. 2009. Comparative analysis of human saliva microbiome diversity by barcoded pyrosequencing and cloning approaches [en ligne]. Anal. Biochem. 391(1) : 64-68. doi: 10.1016/j.ab.2009.04.034.

Nelson-Filho, P., Borba, I.G., Mesquita, K.S., Silva, R.A., Queiroz, A.M., Silva, L.A. 2013. Dynamics of microbial colonization of the oral cavity in newborns [en ligne]. Braz. Dent. J. 24(4) : 415-419. doi: 10.1590/0103-6440201302266.

Nomura, M., Kamata, M., Kojima, H., Hayashi, K., Sawada, S. 2013. Irsogladine maleate reduces the incidence of fluorouracil-based chemotherapy-induced oral mucositis [en ligne]. Ann. Oncol. 24(4) : 1062-1066. doi: 10.1093/annonc/mds584.

Nosho, K., Sukawa, Y., Adachi, Y., Ito, M., Mitsuhashi, K., Kurihara, H. et al. 2016. Association of Fusobacterium nucleatum with immunity and molecular alterations in colorectal cancer [en ligne]. World. J. Gastroenterol. 22(2):557-66. doi: 10.3748/wjg.v22.i2.557.

Nugent, Z. 2010. Periodontal disease may be associated with oral and gastrointestinal cancer [en ligne]. J. Evid. Based Dent. Pract. 10(4) : 223-224. doi: 10.1016/j.jebdp.2010.09.012. 
Ordovas, J.M., Mooser, V. 2006. Metagenomics: the role of the microbiome in cardiovascular diseases. Curr. Opin. Lipidol. 17(2) : 157-161.

Park, O.J., Yi, H., Jeon, J.H., Kang, S.S., Koo, K.T., Kum, K.Y. et al. 2015. Pyrosequencing analysis of sublingual microbiota in distinct periodontal conditions [en ligne]. J. Dent. Res. 94(7) : 921-927. doi: $10.1177 / 0022034515583531$.

Park, S.Y., Kim, M.S., Eom, J.S., Lee, J.S., Rho, Y.S. 2016. Risk factors and etiology of surgical site infection after radical neck dissection in patients with head and neck cancer [en ligne]. Korean J. Intern. Med. 31(1) : 162-169. doi: 10.3904/kjim.2016.31.1.162.

Peterson, D.E., Ohrn, K., Bowen, J., Fliedner, M., Lees, J., Loprinzi, C. et al. 2013. Systematic review of oral cryotherapy for management of oral mucositis caused by cancer therapy [en ligne]. Support Care Cancer 21(1) : 327-332. doi: 10.1007/s00520-012-1562-0.

Pintos, J., Black, M.J., Sadeghi, N., Ghadirian, P., Zeitouni, A.G., Viscidi, R.P. et al. 2008. Human papillomavirus infection and oral cancer: a case-control study in Montreal, Canada [en ligne]. Oral Oncol. 44(3) : 242-250.

Prasad, S., Tyagi, A.K., Aggarwal, B.B. 2016 Detection of inflammatory biomarkers in saliva and urine: Potential in diagnosis, prevention, and treatment for chronic diseases. Exp Biol Med. 241(8) :783-799. Prince, A.L., Antony, K.M., Ma, J., Aagaard, K.M. 2014. The microbiome and development: a mother's perspective [en ligne]. Semin. Reprod. Med. 32(1) : 14-22. doi: 10.1055/s-0033-1361818.

Radosevich, A.J., Mutyal, N.N., Rogers, J.D., Gould, B., Hensing, T.A., Ray, D. et al. 2014. Buccal spectral markers for lung cancer risk stratification [en ligne]. PloS One 9(10) : e110157. doi: 10.1371/journal.pone.0110157.

Rogers, G.B., Hoffman, L.R., Carroll, M.P., Bruce, K.D. 2013. Interpreting infective microbiota: the importance of an ecological perspective [en ligne]. Trends Microbiol. 21(6) : 271-276. doi: 10.1016/j.tim.2013.03.004.

Sakamoto, M., Suzuki, M., Umeda, M., Ishikawa, I., Benno, Y. 2002. Reclassification of Bacteroides forsythus (Tanner et al. 1986) as Tannerella forsythensis corrig., gen. nov., comb. nov. Int. J. Syst. Evol. Microbiol. 52(Pt 3) : 841-849. 
Sasaki, M., Yamaura, C., Ohara-Nemoto, Y., Tajika, S., Kodama, Y., Ohya, T. et al. 2005. Streptococcus anginosus infection in oral cancer and its infection route. Oral Dis. 11(3) : 151-156.

Scannapieco, F.A., Genco, R.J. 1999. Association of periodontal infections with atherosclerotic and pulmonary diseases. J. Periodontal Res. 34(7) : 340-345.

Shao, Z.Y., Tang, Z.S., Yan, C., Jiang, Y.T., Ma, R., Liu, Z. et al. 2011. Effects of intensity-modulated radiotherapy on human oral microflora. J. Radiat. Res. 52(6) : 834-839.

Shiga, K., Tateda, M., Saijo, S., Hori, T., Sato, I., Tateno, H. et al. 2001. Presence of Streptococcus infection in extra-oropharyngeal head and neck squamous cell carcinoma and its implication in carcinogenesis. Oncol. Rep. 8(2) : 245-248.

Shiga, K., Ogawa, T., Maki, A., Amano, M., Kobayashi, T. 2011. Concomitant chemoradiotherapy as a standard treatment for squamous cell carcinoma of the temporal bone [en ligne]. Skull Base 21(3) : 153-158. doi: 10.1055/s-0031-1275244.

Sinha, A., Chandra, S., Raj, V., Zaidi, I., Saxena, S., Dwivedi, R. 2015. Expression of p63 in potentially malignant and malignant oral lesions [en ligne]. J. Oral Biol. Craniofac. Res. 5(3) :165-172. doi: 10.1016/j.jobcr.2015.07.001.

Sivadasan, P., Gupta, M.K., Sathe, G.J., Balakrishnan, L., Palit, P., Gowda, H. et al. 2015. Human salivary proteome - a resource of potential biomarkers for oral cancer [en ligne]. J. Proteomics 127(Pt A) : 89-95. doi: 10.1016/j.jprot.2015.05.039.

Sixou J.L., Aubry-Leuliette A., De Medeiros-Battista, O., Lejeune, S., Jolivet-Gougeon, A., SolhiPinsard, H. et al. 2006. Capnocytophaga in the dental plaque of immunocompromised children with cancer. Int. J. Paediatr. Dent. 16(2) : 75-80.

Soares, A.F., Aquino A.R., Carvalho, C.H., Nonaka, C.F., Almeida, D., Pinto, L.P. 2011. Frequency of oral mucositis and microbiological analysis in children with acute lymphoblastic leukemia treated with 0.12\% chlorhexidine gluconate. Braz. Dent. J. 22(4) : 312-316.

Soder, B., Yakob, M., Meurman, J.H., Andersson, L.C., Klinge, B., Soder, P.O. 2011. Periodontal disease may associate with breast cancer [en ligne]. Breast Cancer Res. Treat. 127(2) : 497-502. doi: 10.1007/s10549-010-1221-4. 
Souto, R., Colombo, A.P. 2008. Detection of Helicobacter pylori by polymerase chain reaction in the subgingival biofilm and saliva of non-dyspeptic periodontal patients [en ligne]. J. Periodontol. 79(1) : 97-103. doi: 10.1902/jop.2008.070241.

Stanko, P., Kruzliak, P., Labas, P. 2013. Role of human papilloma virus infection and oral-genital contact in oral cancer ethiopathogenesis. Bratisl. Lek. Listy. 114(6) : 345-348.

Steffen, M.J., Holt, S.C., Ebersole, J.L. 2000. Porphyromonas gingivalis induction of mediator and cytokine secretion by human gingival fibroblasts. Oral Microbiol. Immunol. 15(3) : 172-180.

Su, H., Yan, X., Dong, Z., Chen, W., Lin, Z.T., Hu, Q.G. 2015. Differential roles of Porphyromonas gingivalis lipopolysaccharide and Escherichia coli lipopolysaccharide in maturation and antigenpresenting functions of dentritic cells. Eur. Rev. Med. Pharmacol. Sci. 19(13) : 2482-2492.

Takahashi, N. 2015. Oral microbiome metabolism: from « who are they? » to " what are they doing? » [en ligne]. J. Dent. Res. 94(12) : 1628-1637. doi: 10.1177/0022034515606045.

Targosz, A., Brzozowski, T., Pierzchalski, P., Szczyrk, U., Ptak-Belowska, A., Konturek, S.J., et al. 2012. Helicobacter pylori promotes apoptosis, activates cyclooxygenase (COX)-2 and inhibits heat shock protein HSP70 in gastric cancer epithelial cells [en ligne]. Inflamm. Res. 61(9) : 955-966. doi: 10.1007/s00011-012-0487-x.

Torres, P.J., Fletcher, E.M., Gibbons, S.M., Bouvet, M., Doran, K.S., Kelley, S.T. 2015. Characterization of the salivary microbiome in patients with pancreatic cancer [en ligne]. Peer J. 3:e1373. doi: 10.7717 /peerj.1373

Turner, L., Mupparapu, M., Akintoye, S.O. 2013. Review of the complications associated with treatment of oropharyngeal cancer: A Guide to the dental practitioner [en ligne]. Quintessence Int. 44(3) : 267-279. doi: 10.3290/j.qi.a29050.

Vasconcelos, R.M., Sanfilippo, N., Paster, B.J., Kerr, A.R., Li, Y., Ramalho, L. et al. 2016. HostMicrobiome Cross-talk in Oral Mucositis [en ligne]. J. Dent. Res. 95(7) : 725-733. doi: 10.1177/0022034516641890.

Wade, W.G. 2013. The oral microbiome in health and disease [en ligne]. Pharmacol. Res. 69(1) : 137-143. doi: 10.1016/j.phrs.2012.11.006. 
Wagner, K.W., Schön, R., Schumacher, M., Schmelzeisen, R., Schulze, D. 2006. Case report: brain and liver abscesses caused by oral infection with Streptococcus intermedius. Oral Surg. Oral Med. Oral Pathol. Oral Radiol. Endod. 102(4) : e21-23.

Wang, C., Li, J. 2015. Pathogenic microorganisms and pancreatic cancer [en ligne]. Gastrointest. Tumours 2(1) : 41-47. doi: 10.1159/000380896.

Wilson, A.J., Nussey, D.H. 2010. What is individual quality? An evolutionary perspective [en ligne]. Trends Ecol. Evol. 25(4) : 207-214. doi: 10.1016/j.tree.2009.10.002.

Wood, L.F., Chahroudi, A., Chen, H.L., Jaspan, H.B., Sodora, D.L. 2013. The oral mucosa immune environment and oral transmission of HIV/SIV [en ligne]. Immunol. Rev. 254(1) : 34-53. doi: 10.1111/imr.12078.

Yan, X., Xinmin, Y., Yang, M., Liu, J., Gao, R., Hu, J., Li, J. et al. 2015. Discovery and validation of potential bacterial biomarkers for lung cancer. Am J Cancer Res. 5(10) : 3111-3122.

Young, J.P., Young, P.H. 2005. Meningioma associated with abscess formation-a case report. Surg. Neurol. 63(6) :584-585.

Yu, G., Gail, M.H., Shi, J., Klepac-Ceraj, V., Paster, B.J., Dye, B.A. et al. 2014. Association between upper digestive tract microbiota and cancer predisposing states in the oesophagus and stomach [en ligne]. Cancer Epidemiol. Biomark. Prev. 23(5) : 735-741. doi: 10.1158/1055-9965.EPI-13-0855.

Wade, W.G. 2013. The oral microbiome in health and disease [en ligne]. Pharmacol. Res. 69(1) : 137-143. doi: 10.1016/j.phrs.2012.11.006.

Wilson, A.J., Nussey, D.H. 2010. What is individual quality? An evolutionary perspective [en ligne]. Trends Ecol. Evol. 25(4) : 207-214. doi: 10.1016/j.tree.2009.10.002.

Zahnd, G., Vray, D., Sérusclat, A., Alibay, D., Bartold, M., Brown, A. et al. 2012. Longitudinal displacement of the carotid wall and cardiovascular risk factors: associations with aging, adiposity, blood pressure and periodontal disease independent of cross-sectional distensibility and intimamedia thickness [en ligne]. Ultrasound Med. Biol. 38(10) : 1705-1715. doi: 10.1016/j.ultrasmedbio.2012.05.004. 
Zahran, F., Ghalwash, D., Shaker, O., Al-Johani, K., Scully, C. 2015. Salivary microRNAs in oral cancer [en ligne]. Oral Dis. 21(6) : 739-747. doi: 10.1111/odi.12340.

Zasloff, M. 2002. Antimicrobial peptides of multicellular organisms. Nature 415(6870) : 389-395.

Zaura, E., Nicu, E.A., Krom, B.P., Keijser, B.J. 2014. Acquiring and maintening a normal oral microbiome: current perspective [en ligne]. Front. Cell. Infect. Microbiol. 4 : 85 . doi: 10.3389/fcimb.2014.00085.

Zhang, F., He, S., Jin, J., Dong, G., Wu, H. 2015. Exploring salivary microbiota in AIDS patients with different periodontal statuses using 454 GS-FLX Titanium pyrosequencing [en ligne]. Front. Cell. Infect. Microbiol. 5 : 55. doi: 10.3389/fcimb.2015.00055.

Zhang, X., Zhang, D., Jia, H., Feng, Q., Wang, D., Liang, D. et al. 2015. The oral and gut microbiomes are perturbed in rheumatoid arthritis and partly normalized after treatment [en ligne]. Nat. Med. 21(8) : 895-905. doi: 10.1038/nm.3914.

Zhu, G., Lin, J.C., Kim, S.B., Bernier, J., Agarwal, J.P., Vermorken, J.B. et al. 2016. Asian expert recommendation on management of skin and mucosal effects of radiation, with or without the addition of cetuximab or chemotherapy, in treatment of head and neck squamous cell carcinoma [en ligne]. BMC Cancer. 16 : 42. doi: 10.1186/s12885-016-2073-z. 


\section{Tables legends:}

Table 1: Epidemiologic studies of the HADT microbiome and cancer (Michaud et al. 2013; Yu et al. 2014; Mima et al. 2015; Mitsuhashi et al. 2015; Yan et al. 2015; Chen et al. 2016; Fan et al. 2015; Guerrero-Preston et al. 2016; Johannesen et al. 2016; Nosho et al. 2016)

Table 2: Comparative dominant microbiota of different human sites (Ahn et al. 2012; Costello et al. 2009; Kim et al. 2009; Lemon et al. 2010; Nasidze et al. 2009; Takahashi et al. 2015)

Table 3: Associations between oral microbiome and carcinogenesis (Shiga et al. 2001; Narikiyo et al. 2004 ; Morita et al. 2004 ; Sasaki et al. 2005 ; Sixou et al. 2006 ; Souto and Colombo 2008; Söder et al. 2010; Wang and Li 2015; Galvão-Moreira and da Cruz 2016; Park et al. 2016)

Table 4: Potential biomarkers for early cancer detection (Aas et al. 2005; Fabian and Pachev 2008; Jimenez Torres et al. 2009; Farrel et al. 2012 ; Monteiro et al. 2012; Michelet and Legouis 2012; Leishman et al. 2012; Chen et al. 2012; Ahn et al. 2012; De Freitas et al. 2013; Momen-Heravi et al. 2014; Sivadasan et al. 2015; Zahran et al. 2015; Sinha et al. 2015) 


\begin{tabular}{|c|c|c|c|c|c|c|}
\hline Authors & $\begin{array}{c}\text { Cancer } \\
\text { localisation }\end{array}$ & $\begin{array}{l}\text { Number of } \\
\text { patients }\end{array}$ & Technique & Results & Oral hygiene & Biomarkers \\
\hline $\begin{array}{l}\text { Michaud et al. } \\
\text { (2013) }\end{array}$ & Pancreatic cancers & 405 & $\begin{array}{l}\text { Plasma antibody detection } \\
\text { against } 25 \text { oral bacteria }\end{array}$ & $\begin{array}{l}\text { periodontal pathogens are associated with higher risk } \\
\text { for pancreatic cancer }\end{array}$ & Periodontal disease & $\begin{array}{l}\text { Very high correlations were observed for the two } \\
\text { strains of } P \text {. gingivalis and } A \text {. } \\
\text { actinomycetemcomitans. }\end{array}$ \\
\hline $\begin{array}{l}\text { Yu G et al } \\
\text { (2014) }\end{array}$ & $\begin{array}{l}\text { Esophageal squamous } \\
\text { dysplasia precursor } \\
\text { lesion of carcinoma }\end{array}$ & 333 & $\begin{array}{l}\text { HOMIM (Human Oral } \\
\text { Microbe Identification } \\
\text { Microarray) } \\
\end{array}$ & Lower microbial richness in HADT & Poor oral health, & ND \\
\hline $\begin{array}{l}\text { Chen et al. } \\
\text { (2015) }\end{array}$ & $\begin{array}{l}\text { Esophageal squamous } \\
\text { cell carcinoma }\end{array}$ & 171 & $\begin{array}{l}\text { 4-5-4 pyrosequensing of } \\
\text { oral microbiota of saliva }\end{array}$ & $\begin{array}{l}\text { Comparison between salivary bacterial microbiota and } \\
\text { esophageal squamous cell carcinoma (ESCC) }\end{array}$ & Poor oral health & $\begin{array}{l}\text { Decreased carriage of genera Lautropia, Bulleidia, } \\
\text { Catonella, Corynebacterium, Moryella, Peptococcus } \\
\text { and Cardiobacterium in ESCC subjects compared to } \\
\text { non-ESCC subjects }\end{array}$ \\
\hline $\begin{array}{l}\text { Mima et al. } \\
\text { (2015) }\end{array}$ & Colorectal carcinoma & 598 & $\begin{array}{c}\text { Quantitative PCR for } \\
\text { Fusobacterium nucleatum }\end{array}$ & $\begin{array}{l}\text { Associations of the amount of Fusobacterium } \\
\text { nucleatum with T-cell densities in tumor tissue }\end{array}$ & ND & lower density of T-cells in tumor tissue \\
\hline $\begin{array}{l}\text { Fan et al. } \\
\text { ( 2016) }\end{array}$ & Pancreatic cancer & 361 & $\begin{array}{l}\text { bacterial } 16 \mathrm{~S} \text { ribosomal RNA } \\
\text { (16S rRNA) gene sequencing }\end{array}$ & $\begin{array}{l}\text { oral microbiota may play a role in the aetiology of } \\
\text { pancreatic cancer }\end{array}$ & Periodontal disease & $\begin{array}{l}\text { Higher risk with Porphyromonas gingivalis, } \\
\text { Aggregatibacter actinomycetemcomitans. decreased } \\
\text { cancer risk with Fusobacteria phylum and genus } \\
\text { Leptotrichia }\end{array}$ \\
\hline $\begin{array}{l}\text { Mitsuhashi et } \\
\text { al. (2015) }\end{array}$ & Pancreatic cancers & 302 & $\begin{array}{l}\text { DNA extraction and } \\
\text { quantitative PCR for } \\
\text { Fusobacterium } \\
\text { specie }\end{array}$ & $\begin{array}{c}\text { tumor } \\
\text { Fusobacterium } \\
\begin{array}{c}\text { status was not associated with any clinical and } \\
\text { molecular features }\end{array} \\
\end{array}$ & ND & $\begin{array}{l}\text { Fusobacterium species Fusobacterium species is a } \\
\text { promising biomarker of pancreatic cancer }\end{array}$ \\
\hline $\begin{array}{l}\text { Yan et al. } \\
\text { (2015) }\end{array}$ & Lung cancer & 20 & $\begin{array}{l}\text { Salivary microbiota } \\
\text { PCR (qPCR) }\end{array}$ & Association of saliva microbiota with lung cancer. & ND & $\begin{array}{l}\text { Capnocytophaga and Veillonella were significantly } \\
\text { higher in saliva from lung cancer patients }\end{array}$ \\
\hline $\begin{array}{l}\text { Guerrero- } \\
\text { Preston et al. } \\
\text { (2016) }\end{array}$ & $\begin{array}{l}\text { Head and neck } \\
\text { squamous cell } \\
\text { carcinoma }\end{array}$ & 787 & $\begin{array}{l}\text { Saliva microbiota (16S rRNA } \\
\text { metagenomic sequencing) }\end{array}$ & $\begin{array}{c}\text { microbiota associated } \\
\text { with oral cancer, human papilloma virus infection }\end{array}$ & ND & $\begin{array}{l}\text { HNSCC saliva samples associated with: increase in } \\
\text { Lactobacillus and Streptococcus; decrease in } \\
\text { Haemophilus, Neisseria, Gemellaceae and } \\
\text { Aggregatibacter }\end{array}$ \\
\hline $\begin{array}{l}\text { Momen- } \\
\text { Heravi et al. } \\
(2014)\end{array}$ & $\begin{array}{l}\text { oral squamous cell } \\
\text { carcinoma } \\
\text { (OSCC) }\end{array}$ & 34 & qPCR & $\begin{array}{l}\text { Endogenous control miRNA are discriminatory in OSCC } \\
\text { patients. }\end{array}$ & ND & $\begin{array}{l}\text { miRNA profiles in OSCC patients and healthy } \\
\text { controls were distinctively different }\end{array}$ \\
\hline $\begin{array}{l}\text { Nosho et al. } \\
\text { (2016) }\end{array}$ & Colorectal carcinomas & 551 & Metagenomic analyses & $\begin{array}{l}\text { association of } \\
\text { Fusobacterium } \\
\text { with T-cells and } \\
\text { microRNA expression } \\
\end{array}$ & ND & $\begin{array}{l}\text { Fusobacterium nucleatum possesses } \\
\text { immunosuppressive activities by inhibiting human T- } \\
\text { cell responses. }\end{array}$ \\
\hline
\end{tabular}

Table 1: Epidemiologic studies of the HADT microbiome and cancer showing principles results. 


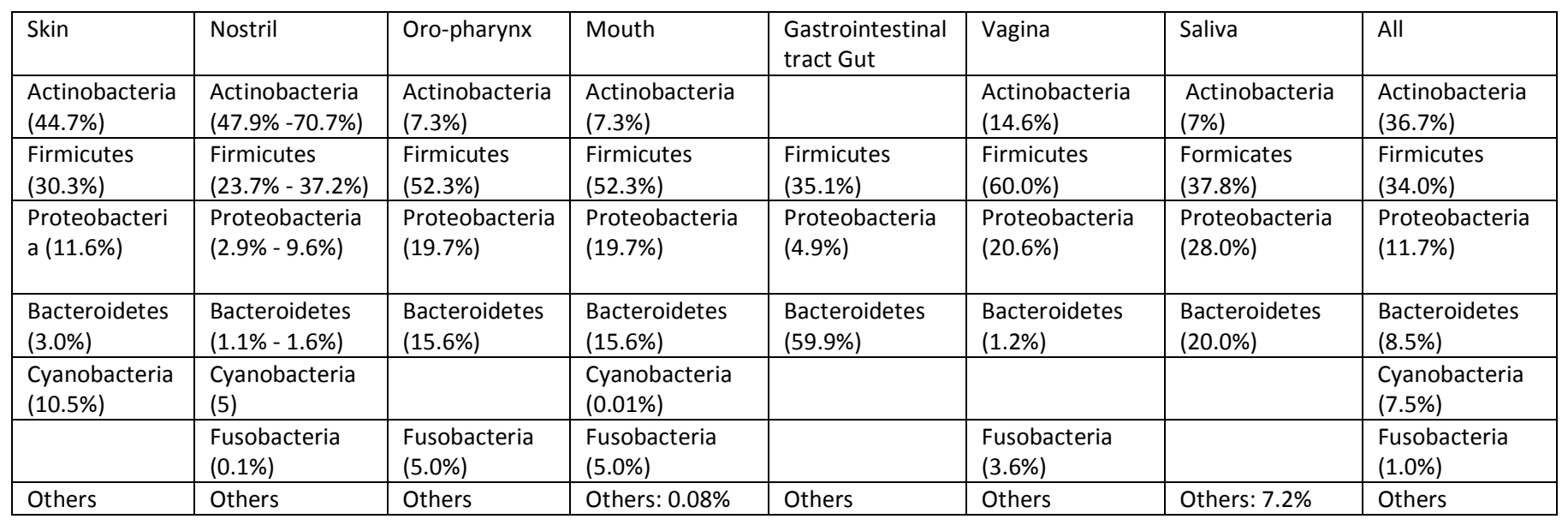

Table 2: Comparative dominant microbiota of different human sites (Ahn et al, 2012; Costello et al, 2009; Kim et al, 2009; Lemon et $a l, 2010$; Nasidze et al, 2009; Takahashi et $a l, 2015$ ) 


\begin{tabular}{|c|c|c|c|c|c|c|c|}
\hline \multirow[t]{2}{*}{ Reference } & \multirow[t]{2}{*}{ Study design } & \multirow[t]{2}{*}{ Cancer } & \multirow[t]{2}{*}{ Study population(s) } & \multicolumn{3}{|c|}{ Population data } & \multirow[t]{2}{*}{ Main findings } \\
\hline & & & & Age & Sex & $\begin{array}{c}\text { Ethnic } \\
\text { group/country }\end{array}$ & \\
\hline $\begin{array}{l}\text { Shiga et } a \text {, } \\
2001\end{array}$ & $\begin{array}{l}\text { Evaluation of the } \\
\text { diversity of bacteria in } \\
\text { the saliva of subjects } \\
\text { with OSCC }\end{array}$ & $\begin{array}{l}\text { Oral } \\
\text { squamous } \\
\text { carcinoma } \\
\text { head and } \\
\text { neck cancer }\end{array}$ & $\begin{array}{l}4 \text { subjects } \\
3 \text { subjects }\end{array}$ & & & Japan & $\begin{array}{l}\text { Using } 454 \text { parallel DNA sequencing, } 58,000 \text { PCR } \\
\text { amplicons that span the V4-V5 hypervariable } \\
\text { region of rRAN from subjects. Fifteen unique } \\
\text { phylotypes were present in all subjects. }\end{array}$ \\
\hline $\begin{array}{l}\text { Narikiyo et } \\
a l, 2004\end{array}$ & $\begin{array}{l}\text { Evaluation of bacterial } \\
\text { diversity in saliva and } \\
\text { in esophageal cancer }\end{array}$ & $\begin{array}{l}\text { esophageal } \\
\text { cancer }\end{array}$ & $\begin{array}{l}20 \text { esophageal cancers tissues } \\
\text { (Japan, Tokyo) } \\
20 \text { healthy oesophageal } \\
\text { tissues } \\
20 \text { healthy patient for saliva } \\
58 \text { esophageal cancer tissue } \\
\text { (Japan) } \\
4 \text { esophageal cancer tissue } \\
\text { (China) } \\
2 \text { esophageal cancer (France) } \\
5 \text { esophageal cancer (Italy) }\end{array}$ & $\begin{array}{l}45-69 \\
\text { Mean } \\
57\end{array}$ & & $\begin{array}{l}\text { Japan (Tokyo) } \\
\text { Japan } \\
\text { Japan } \\
\text { Japan } \\
\text { China } \\
\text { France } \\
\text { Italy }\end{array}$ & $\begin{array}{l}\text { Three periodontitis bacteria (Treponema } \\
\text { denticola, Streptococcus mitis and } \\
\text { Streptococcus anginosus) are present in } \\
\text { oesophageal cancer causing inflammation and } \\
\text { promoting carcinogenic process. } \\
\text { PCR: } 69 \% \text { are + from S. anginosus, } 38 \% \text { for } T \text {. } \\
\text { denticola } \\
\text { PCR: } 91 \% \text { are + from S. anginosus and } 46 \% \text { for } T \text {. } \\
\text { denticola } \\
\text { PCR: } 100 \%+\text { for S. anginosus and } 100 \% \text { for } T \text {. } \\
\text { denticola } \\
\text { PCR: } 100 \%+\text { for S. anginosus and } 40 \% \text { for } T \text {. } \\
\text { denticola }\end{array}$ \\
\hline $\begin{array}{l}\text { Morita et al, } \\
\text { 2004) }\end{array}$ & $\begin{array}{l}\text { Molecular analysis of } \\
\text { age related changes of } \\
\text { Streptococcus } \\
\text { anginosus and S. mitis } \\
\text { in saliva }\end{array}$ & $\begin{array}{l}\text { Healthy } \\
\text { patients } \\
\text { (aging) }\end{array}$ & & & & Japan & $\begin{array}{l}\text { Increase in S. anginosus with age because of its } \\
\text { association with diseases, including cancer }\end{array}$ \\
\hline $\begin{array}{l}\text { Sasaki et al, } \\
2005\end{array}$ & $\begin{array}{l}\text { Streptococcus } \\
\text { anginosus in oral } \\
\text { cancer }\end{array}$ & Oral cancer & $\begin{array}{l}46 \text { subjects (oral cancer) and } 3 \\
\text { precancerous leukoplakia }\end{array}$ & & & Japan & $\begin{array}{l}\text { Infection of } S \text {. Anginosus could occur frequently } \\
\text { in oral squamous cell carcinoma and that dental } \\
\text { plaque could be a dominant reservoir of } S \text {. } \\
\text { anginosus }\end{array}$ \\
\hline $\begin{array}{l}\text { Sixou et } a l \\
2006\end{array}$ & $\begin{array}{l}\text { Capnocytophaga in } \\
\text { the dental plaque of } \\
\text { children with cancer }\end{array}$ & Lymphoma & $\begin{array}{l}31 \text { children with cancer and } 30 \\
\text { healthy control children }\end{array}$ & & & France & $\begin{array}{l}\text { Capnocytophaga decreased in prevalence in the } \\
\text { dental plaque of cancer patients during } \\
\text { chemotherapy but became predominant in } \\
\text { some cases }\end{array}$ \\
\hline $\begin{array}{l}\text { Souto and } \\
\text { Colombo, } \\
2008\end{array}$ & $\begin{array}{l}\text { Detection of } \\
\text { Helicobacter pylori in } \\
\text { saliva }\end{array}$ & & $\begin{array}{l}6 \text { periodontally healthy } \\
\text { subjects and } 169 \text { with chronic } \\
\text { periodontitis }\end{array}$ & & & & $\begin{array}{l}\text { H. pylori was frequently detected in the oral } \\
\text { microbiota of subjects with periodontitis }\end{array}$ \\
\hline
\end{tabular}




\begin{tabular}{|c|c|c|c|c|c|c|c|}
\hline $\begin{array}{l}\text { Söder et al, } \\
2010\end{array}$ & $\begin{array}{l}\text { Periodontal disease } \\
\text { and breast cancer }\end{array}$ & Breast & $\begin{array}{l}3273 \text { subjects } \\
1676 \text { were clinical oral } \\
\text { examination } \\
1597 \text { were not clinically } \\
\text { examined }\end{array}$ & $30-40$ & Women & Sweden & $\begin{array}{l}\text { Chronic periodontal disease indicated by } \\
\text { missing molars seemed to associate statistically } \\
\text { with breast cancer }\end{array}$ \\
\hline $\begin{array}{l}\text { Wang and Li, } \\
2015\end{array}$ & $\begin{array}{l}\text { (Review) } \\
\text { Infections that have } \\
\text { been linked to } \\
\text { pancreatic cancer. }\end{array}$ & $\begin{array}{c}\text { pancreatic } \\
\text { carcinogenes } \\
\text { is }\end{array}$ & Review & - & - & China & $\begin{array}{l}\text { Helicobacter pylori infection may be a risk factor } \\
\text { for pancreatic cancer; chronic hepatitis virus } \\
\text { and oral microbiota may also play a role in } \\
\text { pancreatic carcinogenesis. }\end{array}$ \\
\hline $\begin{array}{l}\text { Galvão- } \\
\text { Moreira and } \\
\text { da Cruz, } 2016\end{array}$ & $\begin{array}{l}\text { (Review) } \\
\text { Relationship between } \\
\text { the oral microbiome, } \\
\text { periodontitis and head } \\
\text { and neck cancer }\end{array}$ & $\begin{array}{l}\text { Head and } \\
\text { neck cancer }\end{array}$ & Review & - & - & & $\begin{array}{l}\text { Evidence have implicated Porphyromonas. } \\
\text { gingivalis and periodontitis in head and neck } \\
\text { rates. }\end{array}$ \\
\hline $\begin{array}{l}\text { Park et al, } \\
2016\end{array}$ & $\begin{array}{l}\text { The risk factors and } \\
\text { microbiological } \\
\text { etiologies. }\end{array}$ & $\begin{array}{l}\text { Head and } \\
\text { neck cancer } \\
\text { (radical neck } \\
\text { dissection) } \\
\end{array}$ & 370 patients & & $\begin{array}{l}\text { Male/fe } \\
\text { male }\end{array}$ & South Korea & $\begin{array}{l}\text { The most common pathogen was methicillin- } \\
\text { resistant Staphylococcus aureus. }\end{array}$ \\
\hline
\end{tabular}

Table 3 Associations between oral microbiome and carcinogenesis. 


\begin{tabular}{|c|c|c|c|c|c|c|c|}
\hline \multirow[t]{2}{*}{ References } & \multirow[t]{2}{*}{ Study design } & \multirow[t]{2}{*}{ Cancer } & \multirow[t]{2}{*}{ Study population (s) } & \multicolumn{3}{|c|}{ Population date } & \multirow[t]{2}{*}{ Main findings } \\
\hline & & & & $\begin{array}{c}\text { Age } \\
\text { (years) }\end{array}$ & Ethnic group & Sex & \\
\hline $\begin{array}{l}\text { Aas et } a l, \\
2005\end{array}$ & $\begin{array}{l}\text { Defining normal human } \\
\text { microflora }\end{array}$ & & 5 subjects & & & & $\begin{array}{l}\text { Specificity of subjects and } 9 \text { sites. } \\
\text { Specificity of periodontal and carie diseases. }\end{array}$ \\
\hline $\begin{array}{l}\text { Fabian and } \\
\text { Pachev, } \\
2008\end{array}$ & $\begin{array}{l}\text { Salivary genomics, } \\
\text { transcriptomics, } \\
\text { proteomics } \\
\text { Review }\end{array}$ & $\begin{array}{l}\text { Early diagnosis of } \\
\text { cancer }\end{array}$ & Review & & & & $\begin{array}{l}\text { The identification of biomarkers with a proper and } \\
\text { definite sensitivity and specificity to as many } \\
\text { disorders and conditions as possible is also a } \\
\text { prerequisite }\end{array}$ \\
\hline $\begin{array}{l}\text { Jimenez } \\
\text { Torres et } a l, \\
2009\end{array}$ & $\begin{array}{l}\text { Periodontitis and } \\
\text { cerebrovascular disease }\end{array}$ & $\begin{array}{l}\text { Cerebrovascular } \\
\text { disease }\end{array}$ & $\begin{array}{l}1137 \text { dentate men in } \\
\text { the }\end{array}$ & $27-84$ & White USA & men & $\begin{array}{l}\text { Stronger correlation with men }<65 \text { years as } \\
\text { compared with men }>65 \text { years old }\end{array}$ \\
\hline $\begin{array}{l}\text { Farrel et } a l, \\
2012\end{array}$ & $\begin{array}{l}\text { Oral microbiota and } \\
\text { cancer risks }\end{array}$ & $\begin{array}{l}\text { Pancreatic } \\
\text { cancers }\end{array}$ & $\begin{array}{l}10 \text { pancreatic } \\
\text { cancers/10 controls } \\
\text { PCR } 28 \text { healthy/27 } \\
\text { chronic pancreatitis } \\
\text { Salivary biomarkers: } \\
\text { PCR (qPCR) }\end{array}$ & & USA & & $\begin{array}{l}\text { Thirthy-one bacteria species are increased in saliva } \\
\text { with patient pancreatic cancer and } 25 \text { bacterial } \\
\text { decreased. Two bacterial (Granulicatella adiacens } \\
\text { and S. mitis) showed significant variation ( } p<0.05) \\
\text { between chronic pancreatitis samples and controls. } \\
\text { This report provides proof of salivary microbiota as } \\
\text { an informative source for discovering non invasive } \\
\text { biomarkers of systemic disease }\end{array}$ \\
\hline $\begin{array}{l}\text { Monteiro et } \\
a l, 2012\end{array}$ & $\begin{array}{l}\text { Cardiovascular risk } \\
\text { marker with periodontal } \\
\text { disease } \\
\text { Measure of LDL (low } \\
\text { density lipoprotein) }\end{array}$ & & $\begin{array}{l}40 \text { patients with } \\
\text { chronic periodontitis }\end{array}$ & & & & $\begin{array}{l}\text { Change in several inflammatory markers show that } \\
\text { the periodontal treatment induces systemic } \\
\text { changes. }\end{array}$ \\
\hline $\begin{array}{l}\text { Michelet } \\
\text { and Legouis, } \\
2012\end{array}$ & $\begin{array}{l}\text { Study selection before } \\
\text { and after radiotherapy } \\
\text { and chemotherapy } \\
\text { Review }\end{array}$ & $\begin{array}{l}\text { Head and neck } \\
\text { cancers }\end{array}$ & $\begin{array}{l}24 \text { cohort, } 8 \text { case } \\
\text { control, } 14 \text { cross } \\
\text { sectional } \\
\text { How many participants } \\
\text { are included is unclear }\end{array}$ & & & & $\begin{array}{l}\text { Patients who were post-radiotherapy had the } \\
\text { highest DMFT compared to those who were post- } \\
\text { chemotherapy and healthy controls }\end{array}$ \\
\hline $\begin{array}{l}\text { Leishman et } \\
\text { al, } 2012\end{array}$ & $\begin{array}{l}\text { Periodontal pathogen } \\
\text { and cardiovascular } \\
\text { disease composition of } \\
\text { human gut microbiota }\end{array}$ & $\begin{array}{l}\text { Myocardial } \\
\text { infarctus }\end{array}$ & 74 patients & & & & $\begin{array}{l}\text { Periodontal pathogens (Porphyromonas gingivalis, } \\
\text { Fusobacterium nucleatum, Tannarella forsythia, } \\
\text { Aggregatibacter actinomycetem) } \\
\text { Serum antibodies to these pathogens GroEL and } \\
\text { hHSP60 antibody } \\
\text { In cardiovascular patients, a greater burden of } \\
\text { subgingival infection with increased levels of P. } \\
\text { gingivalis and T. forsythia is associated. }\end{array}$ \\
\hline $\begin{array}{l}\text { Chen et } a l, \\
2012\end{array}$ & $\begin{array}{l}\text { Relation preterm and } \\
\text { periodontal pathogens }\end{array}$ & & 110 cases & & & & $\begin{array}{l}\text { Porphyromonas gingivalis, Tannerella forsythia, } \\
\text { Treponema denticola in saliva } \\
\text { Porphyromonas gingivalis may be related to } \\
\text { preterm low birth weight }\end{array}$ \\
\hline $\begin{array}{l}\text { Ahn et } a l, \\
2012\end{array}$ & $\begin{array}{l}\text { Porphyromonas gingivalis } \\
\text { serum ATB levels and }\end{array}$ & & 105 patients & ent & & & $\begin{array}{l}\text { Porphyromonas gingivalis is a biomarker for } \\
\text { microbe associated risk of death due to }\end{array}$ \\
\hline
\end{tabular}




\begin{tabular}{|c|c|c|c|c|c|c|c|}
\hline & $\begin{array}{l}\text { orodigestive cancer } \\
\text { morbidity }\end{array}$ & & & & & & $\begin{array}{l}\text { orodigestive cancer. } \\
\text { Independly of periodontal disease, Porphyromoas } \\
\text { gingivalis is a biomarker of orodigestive cancer. }\end{array}$ \\
\hline $\begin{array}{l}\text { De Freitas et } \\
\text { al, } 2013\end{array}$ & $\begin{array}{l}\text { Oral candida in head and } \\
\text { neck cancer }\end{array}$ & $\begin{array}{l}\text { Head and neck } \\
\text { cancers }\end{array}$ & $\begin{array}{l}29 \text { saliva of head and } \\
\text { neck cancers } \\
34 \text { non } \\
\text { institutionalized, } 29 \\
\text { institutionalized }\end{array}$ & & & & $\begin{array}{l}\text { Diversification and non albicans species were } \\
\text { observed in irradied patients on head and neck } \\
\text { treatment associated fungus positiveness. }\end{array}$ \\
\hline $\begin{array}{l}\text { Momen- } \\
\text { Heravi et al, } \\
2014\end{array}$ & $\begin{array}{l}\text { Human salivary } \\
\text { MicroRNAs (miRNAs) }\end{array}$ & Oral cancer & 34 subjects & & USA & & $\begin{array}{l}\text { Overexpression of miRNA- } 27 \mathrm{~b} \text { appeared to be a } \\
\text { promising OSCC salivary biomarker. }\end{array}$ \\
\hline $\begin{array}{l}\text { Sivadasan et } \\
\text { al, } 2015\end{array}$ & $\begin{array}{l}\text { Human salivary } \\
\text { proteome : } \\
\text { Biomarkers }\end{array}$ & Oral cancer & Meta-analyse & $20-50$ & - & $\begin{array}{c}\text { Egality } \\
\text { Men/women }\end{array}$ & $\begin{array}{l}139 \text { proteins which may serve as secretory } \\
\text { markers in oral malignancies. }\end{array}$ \\
\hline $\begin{array}{l}\text { Zahran et al, } \\
2015\end{array}$ & $\begin{array}{l}\text { Markers for malignant } \\
\text { transformation in oral } \\
\text { mocosal lesions }\end{array}$ & $\begin{array}{l}\text { Oral squamous } \\
\text { cell carcinoma }\end{array}$ & 100 subjects & & & & $\begin{array}{l}\text { miRNA-84 tested might a rapid noninvasive for } \\
\text { revealing malignant transformation in oral mucosa } \\
\text { lesions }\end{array}$ \\
\hline $\begin{array}{l}\text { Sinha et al, } \\
2015\end{array}$ & $\begin{array}{l}\text { Immunohistochemical } \\
\text { expression of P63 }\end{array}$ & $\begin{array}{c}\text { oral } \\
\text { carcinogenesis }\end{array}$ & 45 subjects & - & India & - & $\begin{array}{l}\text { p63 expression in oral premalignant and malignant } \\
\text { lesions as compared to the normal oral mucosa. }\end{array}$ \\
\hline
\end{tabular}

Table 4 Potential Biomarkers for early cancer detection 